\title{
Tuning supramolecular aurophilic structures: the effect of counterion, positive charge and solvent
}

Elisabet Aguiló, ${ }^{\mathrm{a}}$ Raquel Gavara, ${ }^{\mathrm{a}}$ Clara Baucells, ${ }^{\mathrm{a}}$ Marta Guitart, ${ }^{\mathrm{a}}$ João Carlos Lima, ${ }^{\mathrm{b}}$

Jordi Llorca $^{\mathrm{c}}$ and Laura Rodríguez ${ }^{\mathrm{a}, *}$

${ }^{a}$ Departament de Química Inorgànica, Universitat de Barcelona, Martí i Franquès 1-

11, 08028 Barcelona, Spain. Fax: +34 934907725; Tel.: +34 934039130. e-mail:

laura.rodriguez@qi.ub.es

${ }^{b}$ LAQV-REQUIMTE, Departamento de Química, CQFB, Universidade Nova de

Lisboa, Monte de Caparica, Portugal.

${ }^{c}$ Institut de Tècniques Energètiques i Centre de Recerca en NanoEnginyeria,

Universitat Politècnica de Catalunya, Diagonal 647,08028 Barcelona, Spain.

\section{Abstract}

The synthesis of the cationic gold(I) complexes $\left[\mathrm{Au}\left(\mathrm{C} \equiv \mathrm{CC}_{5} \mathrm{H}_{4} \mathrm{~N}\right)\left(\mathrm{CH}_{3}-\mathrm{PTA}\right)\right] \mathrm{X}(\mathrm{X}=\mathrm{I}$, 1; $\mathrm{X}=\mathrm{OTf}, 4),\left[\mathrm{Au}\left(\mathrm{C} \equiv \mathrm{CC}_{5} \mathrm{H}_{4} \mathrm{~N}-\mathrm{CH}_{3}\right)(\mathrm{PTA})\right] \mathrm{X}(\mathrm{X}=\mathrm{I}, \mathbf{2} ; \mathrm{X}=\mathrm{OTf}=\mathbf{5}$; PTA = 1,3,5triaza-7-phosphatricyclo[3.3.1.13.7]decane) and $\left[\mathrm{Au}\left(\mathrm{C} \equiv \mathrm{CC}_{5} \mathrm{H}_{4} \mathrm{~N}-\mathrm{CH}_{3}\right)(\mathrm{DAPTA})\right] \mathrm{X}(\mathrm{X}$ $=\mathrm{I}, \quad 3 ; \quad \mathrm{X}=\mathrm{OTf}=\mathbf{6}, \quad$ DAPTA $=$ 3,7-diacetyl-1,3,7-triaza-5phosphabicyclo[3.3.1]nonane) gives cationic complexes showing unexpected supramolecular assemblies in water going from rod-like structures (1) to vesicles ( 2 and 3) and square-like structures (5 and 6). These morphologies are completely different from the fibers previously obtained with their parent neutral complexes $\left[\mathrm{Au}\left(\mathrm{C} \equiv \mathrm{C}_{5} \mathrm{H}_{4} \mathrm{~N}\right)(\mathrm{PTA})\right]$ and $\left[\mathrm{Au}\left(\mathrm{C} \equiv \mathrm{C}_{5} \mathrm{H}_{4} \mathrm{~N}\right)(\mathrm{DAPTA})\right]$. Nevertheless, the introduction of triflate as counterion in $\mathbf{1}$ (complex 4) gives rise to the formation of highly soluble complex in water which does not display any significant aggregation in solution.

These results reveal the importance of the introduction of a positive charge on the global supramolecular assemblies and how the counterion can modify also the resulting package. Interestingly, we have also proved that the aggregation of complexes $\mathbf{2}, \mathbf{3}, \mathbf{5}$ and $\mathbf{6}$ is also affected by the solvent with direct influence on their absorption and emission properties and the global morphology of the aggregates.

Keywords: supramolecular assemblies, gold(I), aurophilicity, rods, vesicles, photophysics, microscopy. 


\section{Introduction}

Topology is taken proper root in material science in order to understand if it can affect materials physical properties at the nano-/mesoscale and can be used to understand and design materials from this new perspective. ${ }^{1}$ This incipient appreciation for the importance of topology is giving rise in the last years to entirely new materials with unusual topologies that lead to either exotic or enhanced properties. ${ }^{2-4}$ Selfassembly of small molecules has received great attention in this field in the past decade, not only because of their fascinating and innumerable supramolecular morphologies (including spherical or cylindrical micelles, vesicles, toroids, rods, ribbons, lamellar platelets, scrolls or nanotubes $)^{5}$ but also due to their potential applications in material science, ${ }^{6}$ mimic biological systems or functions ${ }^{7,8}$ or in molecular devices. ${ }^{9}$

In the last years, gold(I) complexes represent an emerging area of investigation within this field, as they show weak $\mathrm{Au}(\mathrm{I}) \cdots \mathrm{Au}(\mathrm{I})$ aurophilic interactions ${ }^{10}$ which can modulate and govern the resulting assemblies and properties in very different potential applications. ${ }^{11}$ Among the resulting supramolecular structures obtained with low molecular weight gold(I) complexes, recent reports on hydrogelators should be highlighted. ${ }^{12-14}$ The formation of these gels has been driven through non-covalent interactions, which are commonly van der Waals forces, hydrogen bonding, electrostatic attractions and $\pi-\pi$ stacking interactions, together with aurophilic interactions. ${ }^{12}$

Our recent results on the formation of hydrogels from small organometallic complexes containing $\mathrm{Au}(\mathrm{I})$-alkynyl moieties, ${ }^{15-17}$ prompted us to go one step further in the design and synthesis of novel supramolecular nanostructures constituted by selfassembly of small molecules. In particular, we are interested on the understanding of how supramolecular packing can be modulated by modifications of the chemical structure or the environment of small gold(I) organometallic precursors. The design and synthesis of novel self-assembling materials with tunable properties are challenging, but undeniable crucial, and the understanding of the factors that control such properties has aroused much interest in the last few years. ${ }^{18-25}$ We are mainly interested on gold(I) alkynyl complexes, due to their appealing stems from the two-coordinate linear geometry of the metal atom and the linearity of the alkynyl moiety, which together have made them ideal candidates for the exploration of self-assembling functional properties and have grown attention due to their wide range of different properties. ${ }^{11}$ For these reasons, in this work, we report how the 3D assemblies of gold(I) derivatives previously reported by us ${ }^{15,16}$ can be modulated by the introduction of different factors. In fact, we 
have been able to tune the large pre-organized fibrilar structures previously found and convert them into rods, spherical vesicles or square-like morphologies, among others, by the introduction of a positive charge on the chemical structure either at the phosphine (complexes 1 and 4 Chart 1) or at the pyridyl unit (complexes 2, 3, 5 and 6). The influence of the counterion of these positively charged complexes has been also explored together with the effect of the polarity of the solvents in the intermolecular interactions giving rise to unprecedented changes on their photophysical and morphological properties. Very recently, it has been reported about the formation of different structures with Au alkynyl amphiphilic systems with different long alkyl chains. ${ }^{18}$ But the absence of these long alkyl chains in our complexes make them particularly appealing regarding the study of their aggregation processes. And, to the best of our knowledge, this is the first example that shows how the polarity of different solvents and the presence of different counterions can induce the formation of distinct supramolecular structures in solution with this family of compounds. On the other hand, as was observed for the effect of solvent vapours on the resulting luminescent properties of organometallic gold(I) complex crystals, ${ }^{26-30}$ the rearrangements that occur in solution, also affect the emission of the aggregates.

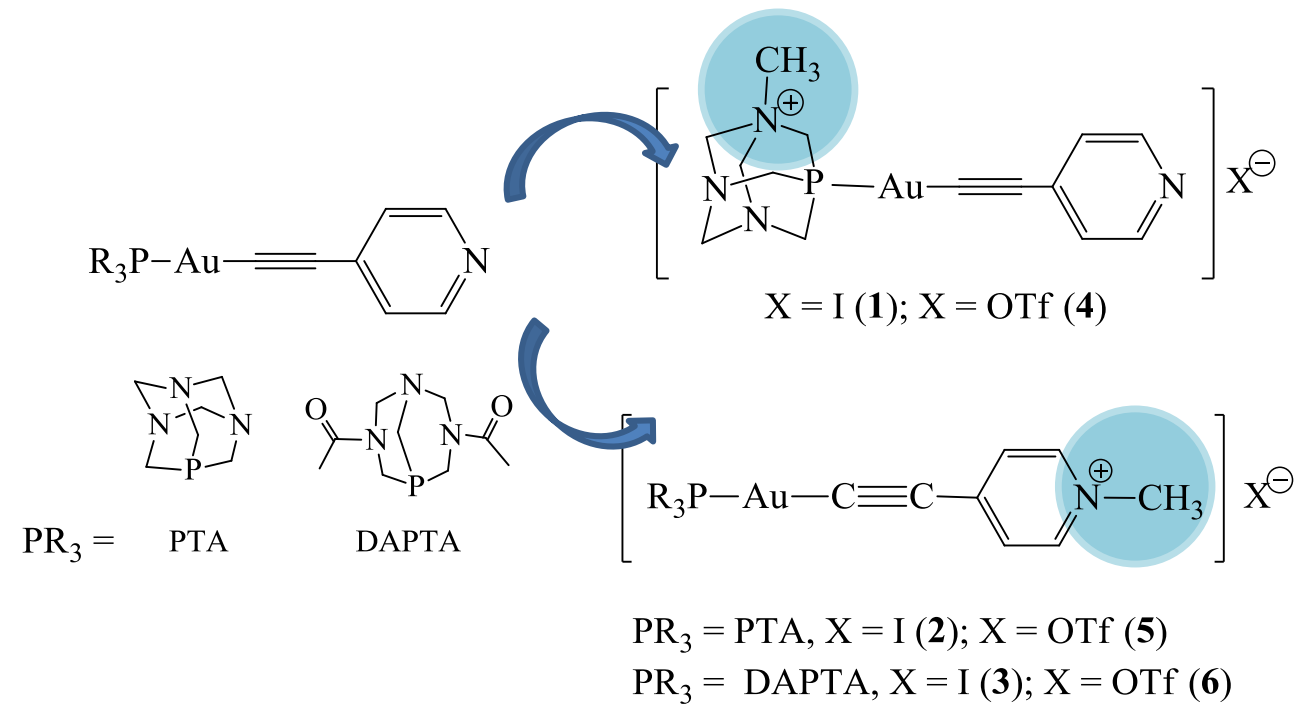

Chart 1. Positively charged species studied in this work. 


\section{Results and Discussion}

\section{Synthesis and Characterization}

Complex 1 was obtained by the reaction of the $\left[\mathrm{Au}\left(\mathrm{C} \equiv \mathrm{CC}_{5} \mathrm{H}_{4} \mathrm{~N}\right)(\mathrm{PTA})\right]$ with $\mathrm{CH}_{3} \mathrm{I}$ at low temperature (Scheme 1). Previously, we assayed the reaction involving $\left[\mathrm{Au}\left(\mathrm{C} \equiv \mathrm{CC}_{5} \mathrm{H}_{4} \mathrm{~N}\right)\right]_{\mathrm{n}}$ and (PTA-Me)I but was unsuccessfully accomplished. On the other hand, positively charged complexes at the pyridyl unit were also obtained by modifications on the synthetic procedures (Scheme 2). For this, the previous synthesis of the organic ligand N-methyl-4-ethynylpyridinum iodide was necessary (Scheme S1). In these cases, the acac method ${ }^{31}$ was necessary to remove the terminal alkynyl proton and obtain complexes $\mathbf{2}$ and $\mathbf{3}$ in moderate yields ( $\mathrm{ca}$. 50\%).

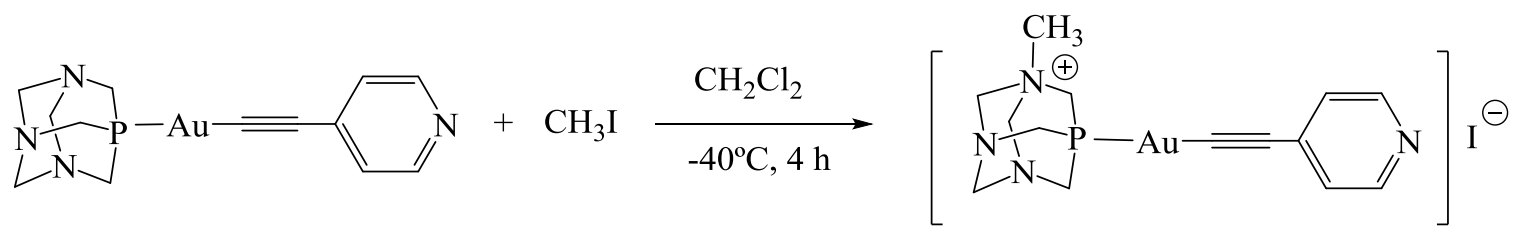

(1)

Scheme 1. Synthesis of $\left[\mathrm{Au}\left(\mathrm{C} \equiv \mathrm{C}_{5} \mathrm{H}_{4} \mathrm{~N}\right)(\mathrm{PTA}-\mathrm{Me})\right] \mathrm{I}$ complex.

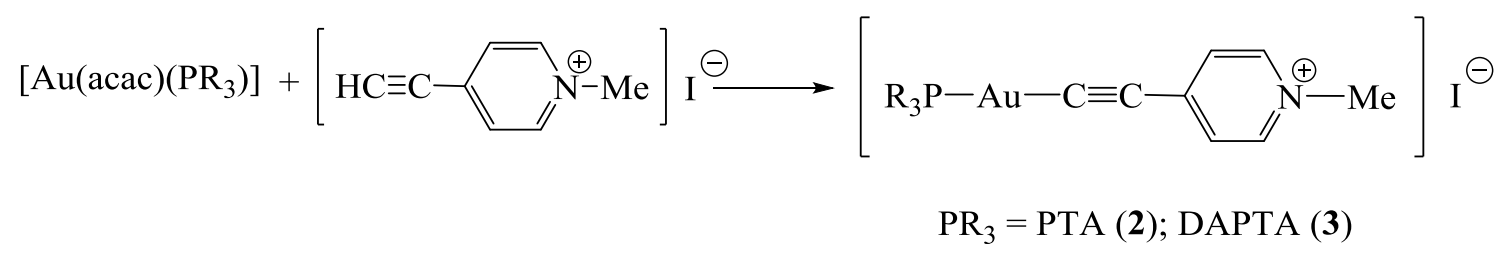

Scheme 2. Synthesis of $\left[\mathrm{Au}\left(\mathrm{C} \equiv \mathrm{C}_{5} \mathrm{H}_{4} \mathrm{~N}-\mathrm{Me}\right)\left(\mathrm{PR}_{3}\right)\right] \mathrm{I}\left(\mathrm{PR}_{3}=\mathrm{PTA}\right.$, DAPTA) complexes.

Characterization of complexes $\mathbf{1 - 3}$ by ${ }^{1} \mathrm{H},{ }^{31} \mathrm{P}-\mathrm{NMR}$, IR spectroscopy and mass spectrometry verified the successful formation of these products. The ESI-MS experiments display the molecular peaks in all cases (Figures S1-S3). IR spectra also show the corresponding $\mathrm{C} \equiv \mathrm{C}$ and $\mathrm{C}=\mathrm{N}$ vibrations of the chromophoric units in all cases. Mainly, the disappearance of the terminal alkynyl proton detected by IR and ${ }^{1} \mathrm{H}-\mathrm{NMR}$ is a clear evidence of the formation of the complexes 2 and 3. Additionally, ${ }^{1} \mathrm{H}-\mathrm{NMR}$ spectra of the complexes show the characteristics $\mathrm{H}_{\alpha}$ and $\mathrm{H}_{\beta}$ protons of the pyridine together with the characteristic patterns of the PTA (2) or DAPTA (3) phosphines in $\mathrm{D}_{2} \mathrm{O}$ (Figures S4 and S5). The formation of aggregated samples in this solvent was evidenced by the presence of different $\mathrm{H}_{\alpha}$ and $\mathrm{H}_{\beta}$ pyridyl protons where this moiety 
must be directly affected. ${ }^{15,16}$ Only phosphine protons are detected in chloroform, due to the poor solubility of the ionic part of the molecules in apolar solvents (Figures S6 and S7). ${ }^{15-17,32-34}$ Moreover, the more asymmetric pattern of the methylated phosphine (1) was also recorded by ${ }^{1} \mathrm{H}-\mathrm{NMR}$ in $\mathrm{D}_{2} \mathrm{O}$ (Figure 1 top). ${ }^{35-37}$ Interesting findings were observed from ${ }^{1} \mathrm{H}-\mathrm{NMR}$ characterization in $\mathrm{D}_{2} \mathrm{O}$. The corresponding spectra of the three complexes clearly displayed the characteristic protons of the phosphines while protons of the ethynylpyridyl chromophore could be only observed (and with very low intensity) at diluted conditions (Figure 1 top). Similar behaviour was recently observed with the $\left[\mathrm{Au}\left(\mathrm{C} \equiv \mathrm{C}_{5} \mathrm{H}_{4} \mathrm{~N}\right)(\mathrm{PTA})\right]^{15}$ complex being a proof of the aggregation process in this solvent, where the organic chromophoric unit must be directly involved. In the absence of aggregation, (as observed in $\mathrm{CDCl}_{3}$, Figure 1 bottom) the ${ }^{1} \mathrm{H}-\mathrm{NMR}$ spectrum shows the correct integration ratio of 2:6 between the pyridyl $\mathrm{H}_{\mathrm{a}}$ and phosphine protons. For the reasons above, some kinds of supramolecular assemblies were also expected for 1-3 in water. Nevertheless, the lack of the expected gel behaviour of the solutions did not indicate the formation of long fibers promoting gelification in these cases (see below).

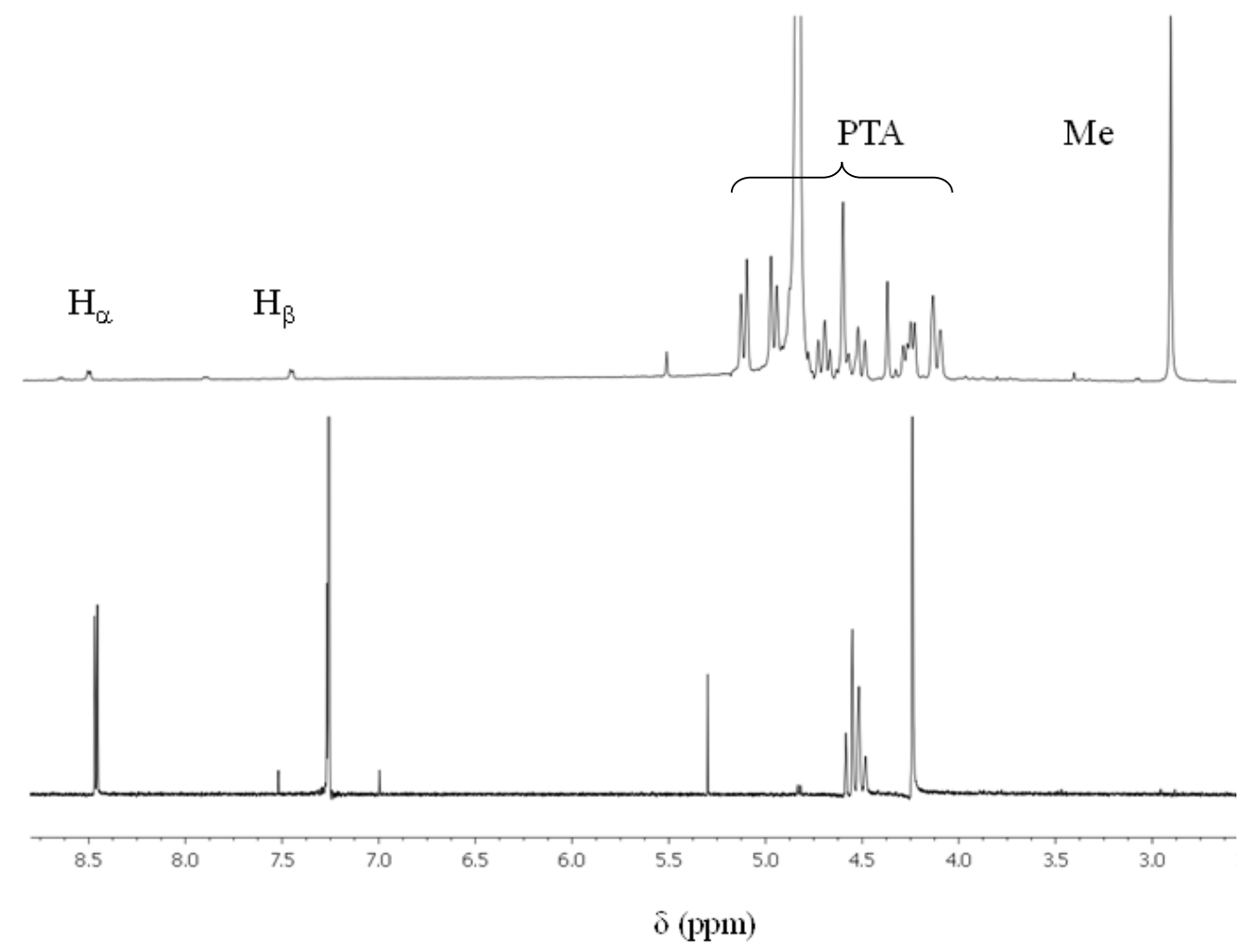

Figure 1. ${ }^{1} \mathrm{H}-\mathrm{NMR}$ spectrum of complex 1 in $\mathrm{D}_{2} \mathrm{O}$ (top) and in $\mathrm{CDCl}_{3}$ (bottom). $\mathrm{H}_{\beta}$ protons in the spectrum below are buried under the $\mathrm{CDCl}_{3}$ signal. 
In $\mathbf{1}$, the phosphine groups are expected to point towards water molecules while the more hydrophobic ethynylpyridyl moieties are expected to pack closely to each other through hydrophobic interactions. In the case of $\mathbf{2}$ and $\mathbf{3}$, the presence of a positive charge at the pyridyl groups is expected to promote a different aggregation pattern, where the positively charged unit is located towards the water molecules. This hypothesis was also confirmed by the $\mathrm{Z}$ potential values measured by DLS experiments (see below).

Analysis of the aggregates by electronic and optical microscopies.

Electronic microscopies were important tools to get insight into the supramolecular assemblies of these complexes and to analyse the effect of the positive moiety (1-3) in the resulting, and unpredictable, three-dimensional supramolecular packing. Rod aggregates of $\mathbf{1}$ are about 20-30 $\mu \mathrm{m}$ length; individual spherical aggregates of $\mathbf{2}$ and $\mathbf{3}$ measure around $20 \mathrm{~nm}$ and the presence of a multilayer system (typical of vesicles) containing in some cases hollows (darker colour) showing its empty inner can be detected for 2 (Figure 2). Moreover, the spherical aggregates seem to agglomerate in ca. $200 \mathrm{~nm}$ sizes or larger (Figure S8). Cryo-TEM images were key evidences to verify the presence of the micellar-vesicles topologies of $\mathbf{2}$ and $\mathbf{3}$ in solution (Figure 2D).

Interestingly, these morphologies seem to be maintained in larger structures detectable by optical microscopy (Figure 3).

Hence, it seems clear that cationic charges produces a clear effect on the global morphology of the supramolecular assemblies and precludes the formation of long empty fibers previously observed for their neutral analogous complexes $\left[\mathrm{Au}\left(\mathrm{C} \equiv \mathrm{C}_{5} \mathrm{H}_{4} \mathrm{~N}\right)(\mathrm{PTA})\right]^{15}$ and $\left[\mathrm{Au}\left(\mathrm{C} \equiv \mathrm{C}_{5} \mathrm{H}_{4} \mathrm{~N}\right)(\mathrm{DAPTA})\right] .{ }^{16}$ 

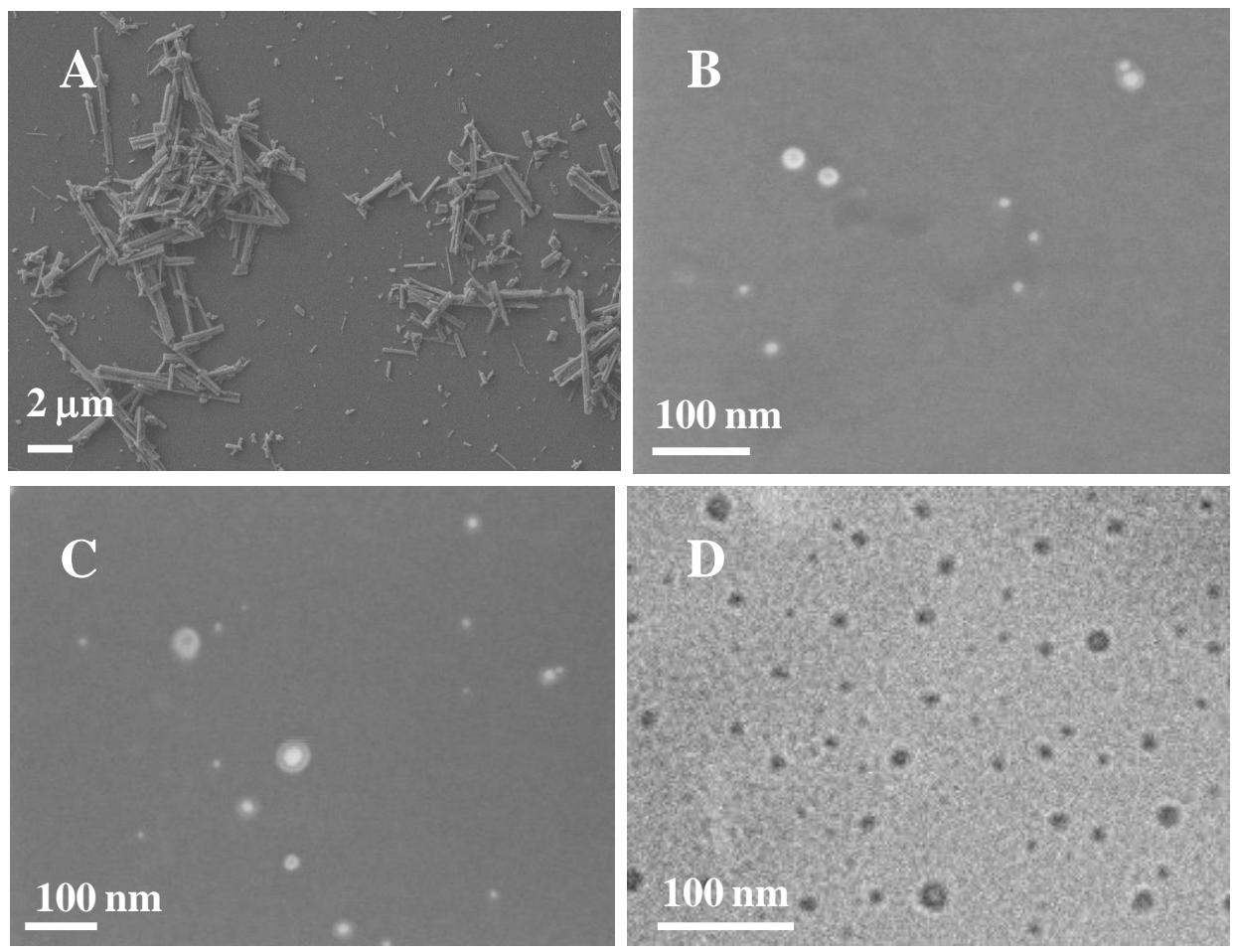

Figure 2. Scanning electron microscopy images of dried samples of $\mathbf{1}$ (A), 2 (B) and $\mathbf{3}$

(C). Cryo-Transmission electron microscopy image of dried sample of 2 (D).
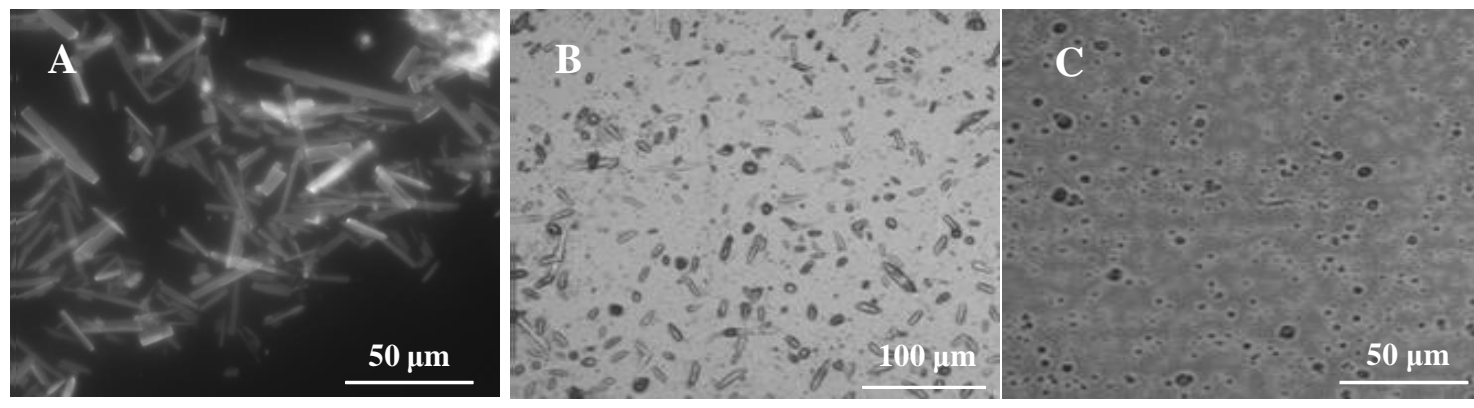

Figure 3. Optical microscopy images of dried samples of $\mathbf{1}$ (A), 2 (B) and $\mathbf{3}$ (C).

\section{Dynamic Light Scattering}

Dynamic Light Scattering experiments were carried out for the spherical samples (vesicles) at $5 \times 10^{-5} \mathrm{M}$ solutions and indicate that the expected size is around 20 $\mathrm{nm}$ with a positive $\mathrm{Z}$ potential value of around +25 and $+15 \mathrm{mV}$ for 2 and 3 respectively (Figure S9). These data suggest that the positive charge may be pointing outwards in the vesicles' structure. The lowest positive value measured for $\mathbf{3}$ could be attributed to the larger steric hindrance of the DAPTA phosphine that must be related to different packing structure (see below). DLS experiments carried out at different concentrations showed that the smaller vesicles' size are detected at $c a .10^{-5} \mathrm{M}(\sim 20$ 
$\mathrm{nm}$ ), and they agglomerate up to $c a .130-140 \mathrm{~nm}$ at $c a .1 \times 10^{-4} \mathrm{M}$ concentration (Figure 4), in agreement with data retrieved from SEM experiments (see above). Thus, we can suspect that the spherical shape is maintained both in solution and in dried samples.
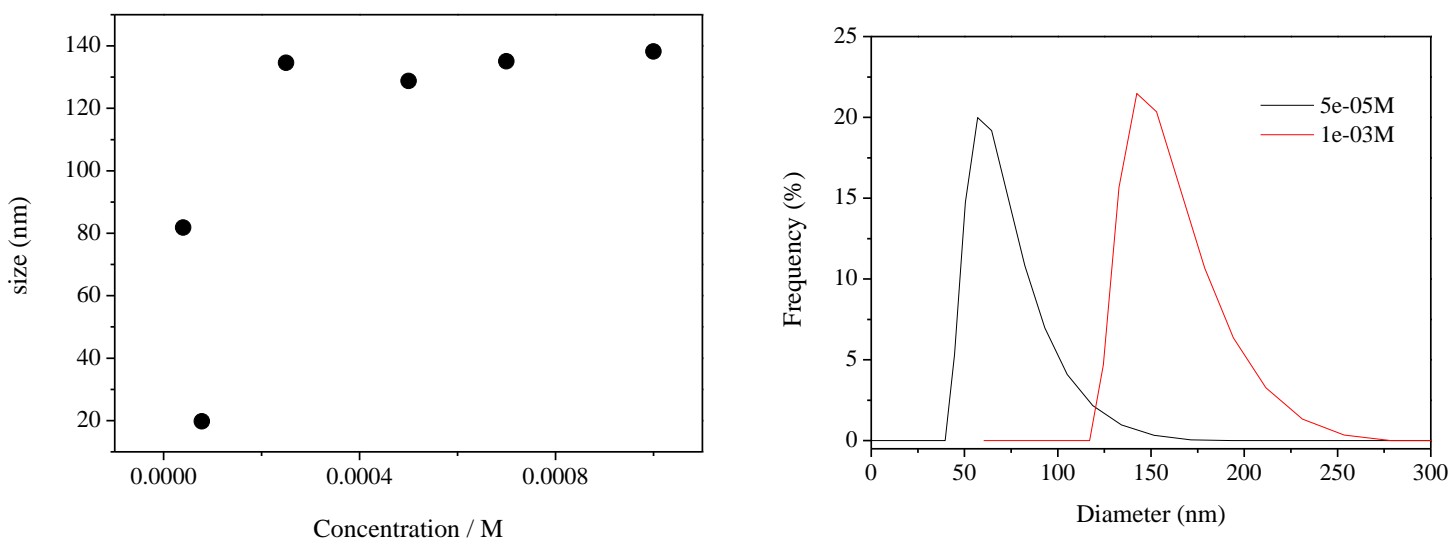

Figure 4. Vesicles' size of different of solutions of $\mathbf{2}$ in water at different concentrations measured by DLS (left); DLS distribution at two different concentrations: $5 \cdot 10^{-5} \mathrm{M}$, black line, and $1 \cdot 10^{-3} \mathrm{M}$, red line (right).

Such vesicles-topology, to the best of our knowledge, is the first example reported in the literature based on weak interactions with low molecular weight complexes. Only small micelles were very recently found with a $\mathrm{Au}(\mathrm{I})$ metalloamphiphile in buffered water. ${ }^{38}$

\section{Effect of counteranion on the resulting package.}

The nature of the counterion can affect the resulting supramolecular package as observed in other gold supramolecular structures. ${ }^{39}$ With this in mind, the complex $\left[\mathrm{Au}\left(\mathrm{C} \equiv \mathrm{C}_{5} \mathrm{H}_{4} \mathrm{~N}\right)(\mathrm{PTA}-\mathrm{Me})\right] \mathrm{OTf}(\mathbf{4})$ was synthesized following a procedure similar to the one used to obtain 1 but using MeOTf instead of MeI. The resulting product was observed to be highly soluble in polar solvents and is shown in the corresponding ${ }^{1} \mathrm{H}$ NMR spectrum in $\mathrm{D}_{2} \mathrm{O}$, which shows all the protons of the molecule in the correct integrating ratio (Figure S10). Thus, no significant aggregation was expected and consequently, complex 4 does not seem to give rise to the formation of highly preorganized and ordered structures.

The synthesis of N-methyl-4-pydidylethynyl triflate ligand was also performed following similar procedure than the corresponding to iodide ligand (Scheme S2) in order to investigate if the counteranion could induce changes on the spherical-type 
aggregates observed for $\mathbf{2}$ and 3. Different attempts were also performed in order to introduce other counteranions such as perchlorate (see Scheme S3) but the very low yield $(\sim 2 \%)$ of the resulting organic precursor and the oily nature of the obtained gold(I) derivatives precluded their correct isolation and corresponding studies.

The reaction of the triflate ligand with $\left[\mathrm{Au}(\mathrm{acac})\left(\mathrm{PR}_{3}\right)\right]\left(\mathrm{PR}_{3}=\mathrm{PTA}, \mathrm{DAPTA}\right)$ was accomplished by the same procedure shown in Scheme 2 for iodide derivatives and the resulting $\left[\mathrm{Au}\left(\mathrm{C} \equiv \mathrm{C}_{5} \mathrm{H}_{4} \mathrm{~N}-\mathrm{Me}\right)\left(\mathrm{PR}_{3}\right)\right] \mathrm{OTf}\left(\mathrm{PR}_{3}=\right.$ PTA (5), DAPTA (6)) were successfully obtained in moderate-high yields ( $\mathrm{ca}$. 70-80\%) in agreement with characterization data (Figures S11 and S12). Optical microscopy images of dried aqueous samples of $\mathbf{5}$ and $\mathbf{6}$ showed the formation of large structures presenting likesquare concentric shape (Figure 5A and S13). SEM characterization confirms this fact and let us to measure their size as $c a$. 20-40 $\mu \mathrm{m}$ (Figure 5B and C and S14). It could be seen that the use of a different counteranion (triflate instead of iodide) modulates the formation of different supramolecular package: squares for triflate complexes instead of micelles/vesicles, observed for iodide derivatives (Table 1).
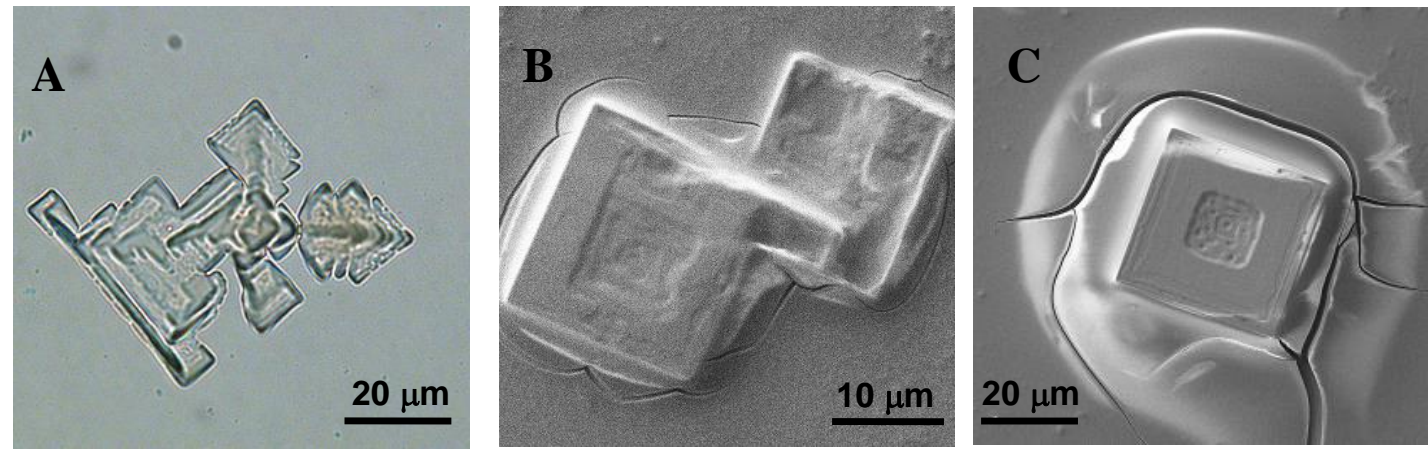

Figure 5. Optical microscopy images of aqueous dried samples of 6 (A). SEM images of aqueous dried samples of 5 (B) and 6 (C).

Table 1. Summary of the different supramolecular assemblies of complexes 1-6 in water.

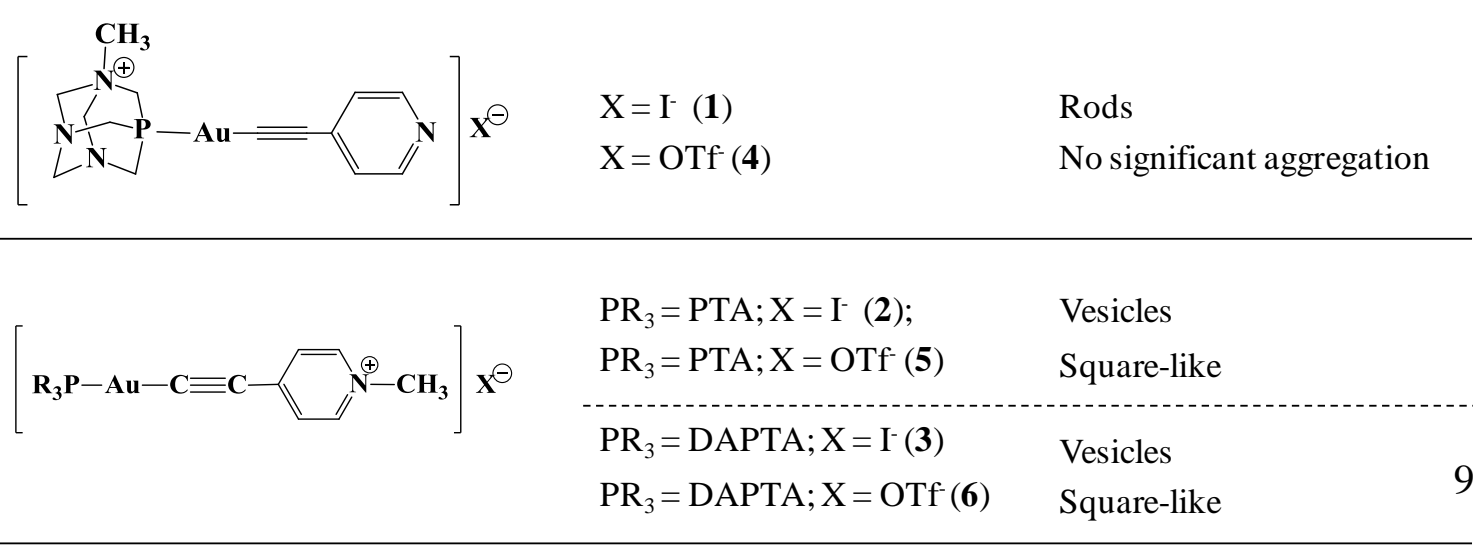




\section{Analysis of the packing parameter and relation with the observed geometry}

It has been seen that the critical packing parameter (CPP) is an important tool to determine the geometry of the micellar type of aggregates. It is based on the calculation of the ratio $\mathrm{v} /\left(l_{\max } * \mathrm{a}\right)$ where $v$ is the volume of one molecule, $l_{\max }$ is length of the hydrophobic part and $a$ the area of a cross section of the more hydrophilic part of the molecule involved in the aggregate. The calculation of the CPP values corresponding to the cationic part of the molecules (involved directly on the packing formation) was carried out by measuring the length of each molecule based on simple Spartan models (Figure 6). The calculated $\mathrm{CPP}$ values are $0.51,1.01$ and 4.07 for $[\mathrm{Au}(\mathrm{C} \equiv \mathrm{C}$ $\left.\left.\mathrm{C}_{5} \mathrm{H}_{4} \mathrm{~N}\right)\left(\mathrm{CH}_{3} \mathrm{PTA}\right)\right]^{+}, \quad\left[\mathrm{Au}\left(\mathrm{C} \equiv \mathrm{C}-\mathrm{C}_{5} \mathrm{H}_{4} \mathrm{~N}-\mathrm{CH}_{3}\right)(\mathrm{PTA})\right]^{+} \quad$ and $\quad\left[\mathrm{Au}\left(\mathrm{C} \equiv \mathrm{C}-\mathrm{C}_{5} \mathrm{H}_{4} \mathrm{~N}-\right.\right.$ $\mathrm{CH}_{3}$ )(DAPTA) $]^{+}$respectively. This is in agreement with the formation of hexagonal preferred aggregate structures for the complex with the cationic charge located at the phosphine (Figure 6 left) and lamellar aggregates (Figure 6 middle) and reversed micelles (Figure 6 right) for the aggregation of complexes with the positive charge at the pyridyl moiety and PTA and DAPTA phosphines respectively. ${ }^{40}$ The lamellar structures tend to minimize the interactions between water molecules and the hydrophobic parts that are inside the lamellar phase. At the same time, the positively charged head groups induces a curvature, closing the structure, that will also minimize the repulsion between the positively charged head groups and results on the formation of a vesicle. ${ }^{41}$ This is in agreement with the characterization images obtained by SEM (see above). Finally, the high steric hindrance of the DAPTA phosphine must be the responsible of the formation of reversed micelles, instead of vesicles, where the most bulky group (phosphine) is located outside the cavity. The presence of amines in this phosphine makes this location possible since amine may be protonated at neutral aqueous $\mathrm{pH}$. 


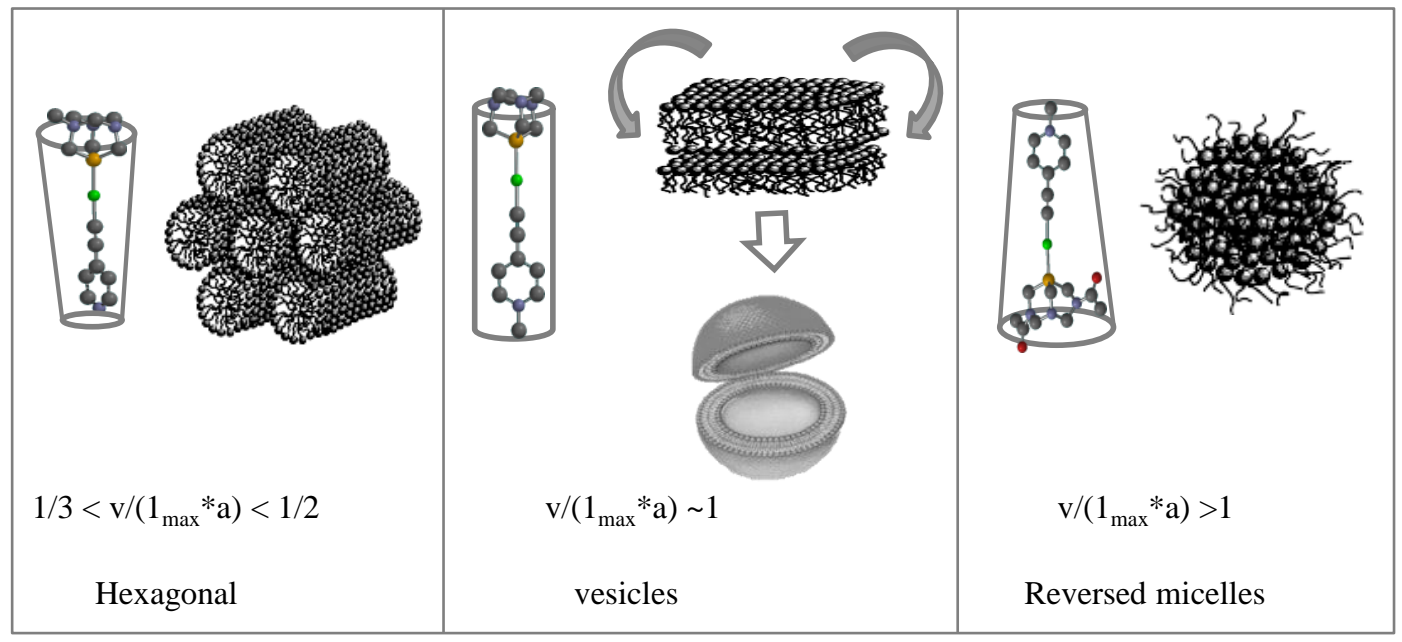

Figure 6. Critical packing parameters (CPPs) and preferred aggregate structures for geometrical packing reasons of $\left[\mathrm{Au}\left(\mathrm{C} \equiv \mathrm{C}-\mathrm{C}_{5} \mathrm{H}_{4} \mathrm{~N}\right)\left(\mathrm{CH}_{3} \mathrm{PTA}\right)\right]^{+}(\mathrm{left}),\left[\mathrm{Au}\left(\mathrm{C} \equiv \mathrm{C}-\mathrm{C}_{5} \mathrm{H}_{4} \mathrm{~N}-\right.\right.$ $\left.\left.\mathrm{CH}_{3}\right)(\mathrm{PTA})\right]^{+}$(middle) and $\left[\mathrm{Au}\left(\mathrm{C} \equiv \mathrm{C}-\mathrm{C}_{5} \mathrm{H}_{4} \mathrm{~N}-\mathrm{CH}_{3}\right)(\mathrm{DAPTA})\right]^{+}$(right).

It is known that simple inorganic counterions are very loosely associated with the micelles. They are very mobile and there is no specific complex formed with a defined distance with the external part of the micelle. For this, iodide counterions of 1-3 are not expected to affect the resulting packages and CPP could give a reasonable explanation for the packing.

We are not convinced that the same is true for triflate derivatives 4-6, due to its lower water solubility and the evidence for a possible anion- $\pi$ interaction with compound 4 (see below). The very different structures for the aggregates of 5 and $\mathbf{6}$ suggests that the packing must take into account the possible intercalation of triflate in the aggregates, despite we cannot proof this. In such a case (triflate intercalation in the structure) repulsions between the positive moieties may be less important and for this, the resulting packages are extended structures of lamellar phase giving rise to squarelike samples instead of vesicles.

Several attempts carried out to grow single crystals suitable for X-ray diffraction were unsuccessful. In order to gain more information about the crystal packing, powder DRX experiments were performed for complexes $\mathbf{2}$ and $\mathbf{5}$ that differ on the counterion (Figure S15). The results show a crystalline packing for the iodide complex while amorphous for the triflate structure. This fact can be tentatively assigned to a previous organization of the organometallic iodide derivatives in the powder that could be in agreement with the fact that in these cases, counterion is outside the supramolecular assemblies in vesicles and micelles already before solubilization in water. Nevertheless, 
it seems credible that the observed organizations studied in this work are globally resulting of assemblies in solution.

\section{Effect of the solvent on the resulting package}

Diluted solutions of complexes $\mathbf{2}$ and $\mathbf{3}$ present different colours in polar and apolar solvents. For this, the effect of the polarity of the solvent on the resulting spectroscopic properties and morphology was investigated.

\section{Absorption and emission characterization in water}

Absorption and emission spectra of the complexes 1-6 were recorded in water at ca. $10^{-5} \mathrm{M}$ concentration and the results are summarized in Table S1 and Figures 7, S16 and 8. The absorption spectrum of $\mathbf{1}$ presents an intense absorption at ca. 265-300 assigned to intraligand (IL) $\pi-\pi^{*}(\mathrm{C} \equiv \mathrm{Cpy})$ transitions based on literature. ${ }^{11,15,16,42,43}$ This transition exhibits some broadening (not completely vibronically resolved) which is indicative of an aggregation process where the Au-C $\equiv$ Cpy moiety is directly involved. ${ }^{15}$ Thus, $\pi-\pi$ stacking together with aurophilic interactions are expected to be present in solution and should be responsible for the formation of the rod-like structures. A lower intensity broad band or tail above $300 \mathrm{~nm}$ can be assigned to a $\sigma^{*}{ }_{\mathrm{Au} \cdots \mathrm{Au}}-\pi^{*}$ transition according to theoretical studies carried out recently for analogous neutral complexes. $^{42,44}$ The intraligand absorption band of 2-6 is about $20 \mathrm{~nm}$ red-shifted and without vibronical resolution. In the case of $\mathbf{2}, \mathbf{3}, \mathbf{5}$ and $\mathbf{6}$, this is due to the methylated pyridyl group.

Another band around $400 \mathrm{~nm}$ is recorded for the PTA complexes 2 and 5. This band should be due to the absorption of aggregated species since PTA complexes aggregate easier than their DAPTA analogous. An additional transition around $450 \mathrm{~nm}$ was recorded for fresh solutions of $\mathbf{2}$ and $\mathbf{3}$ which has been tentatively assigned to XLCT transitions ( $\mathrm{X}=$ halide), as reported in the literature for other organometallic compounds. ${ }^{45,46}$ This charge transfer transition is favoured by the coordination of an electrowithdrawing group (Au-phosphine) to the pyridinium moiety ${ }^{47}$ and was observed to disappear in aged solutions (Figure S17). This could be probably due to a reorganization of the iodide anions in the aggregates with time.

A particular profile was displayed by 4 (Figure S16). The highest recorded extinction coefficient is in agreement with the lack of formation of aggregates. Nevertheless, the profile is not completely understood since it resembles the spectra of the methylated 
pyridyl derivatives $(\mathbf{2}, \mathbf{3}, \mathbf{5}$ and $\mathbf{6})$ but the ${ }^{1} \mathrm{H}-\mathrm{NMR}$ spectra does not show any upfield shift typical for this coordination. The largest ${ }^{1} \mathrm{H}-\mathrm{NMR}$ downfield shift of $\mathrm{H}_{\alpha}$ and $\mathrm{H}_{\beta}$ protons of $\mathbf{4}$ together with the smaller calculated coupling constants, are in agreement with a possible anion- $\pi$ stacking disposition. ${ }^{48}$ Thus, triflate counterion could interact with the aromatic pyridyl ring giving to a red-shifted and unresolved absorption band. These interactions may be favoured with this counterion due to the possibility to establish hydrogen bonding and could be the reason for the different package observed by SEM.

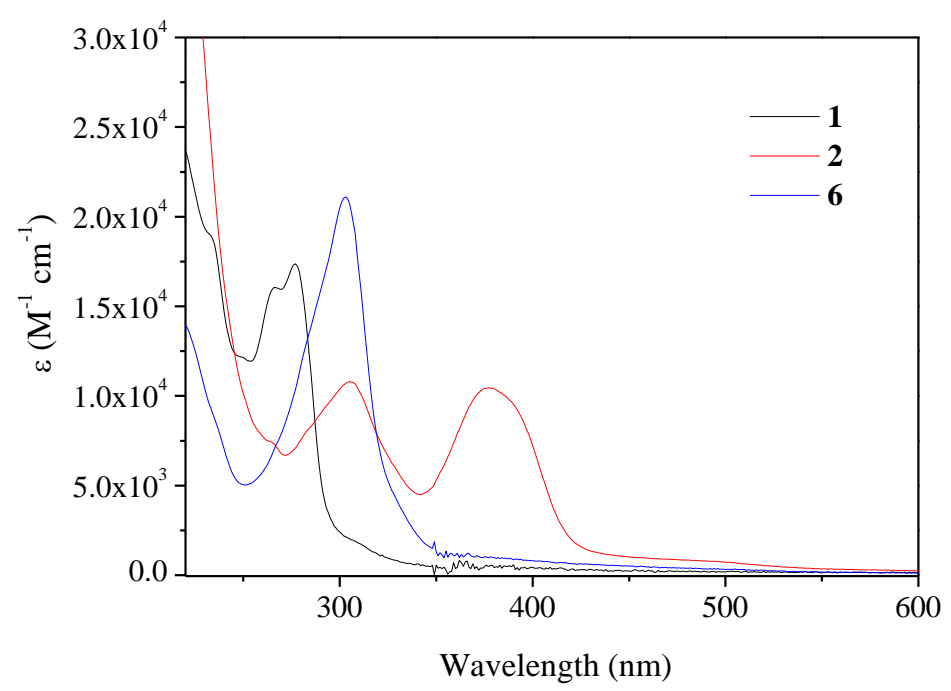

Figure 7. Absorption spectra of $5 \times 10^{-5} \mathrm{M}$ solutions of complexes $\mathbf{1 , 2}$ and $\mathbf{6}$ in water.

Emission spectra, recorded upon excitation all the samples at $370 \mathrm{~nm}$, display the presence of a broad band around $450 \mathrm{~nm}$ (or vibronically structured with progressional spacings at $c a .2000 \mathrm{~cm}^{-1}$, in the case of 1) and an additional band near $600 \mathrm{~nm}$ for the PTA derivatives 1, 2 and 5 (Figure 8). The vibronical structuration observed in 1 let us to assign this higher energy band to an intraligand ${ }^{3}\left[\pi-\pi^{*}\right.$ (alkynyl) $]$ emission origin. This resolution is lost for methylated pyridyl derivatives $\mathbf{2}, \mathbf{3}, \mathbf{5}$ and $\mathbf{6}$, as observed in other methyl-pyridinium compounds. ${ }^{45,46,49}$ The lower energy emissions may be attributed to MMLCT transitions within the aggregates as recently observed for platinum alkynyl derivatives and for the emission spectra recorded at different concentrations (Figure S18). ${ }^{50,51}$ The recorded yellow emission is also in agreement with this assignment and with the fact that approximation of Au centers increases the emission in this region of the spectrum. ${ }^{42}$ An XLCT origin should be ruled out since it is also observed for triflate derivatives and also for aged solutions where the XLCT absorption band disappears. 


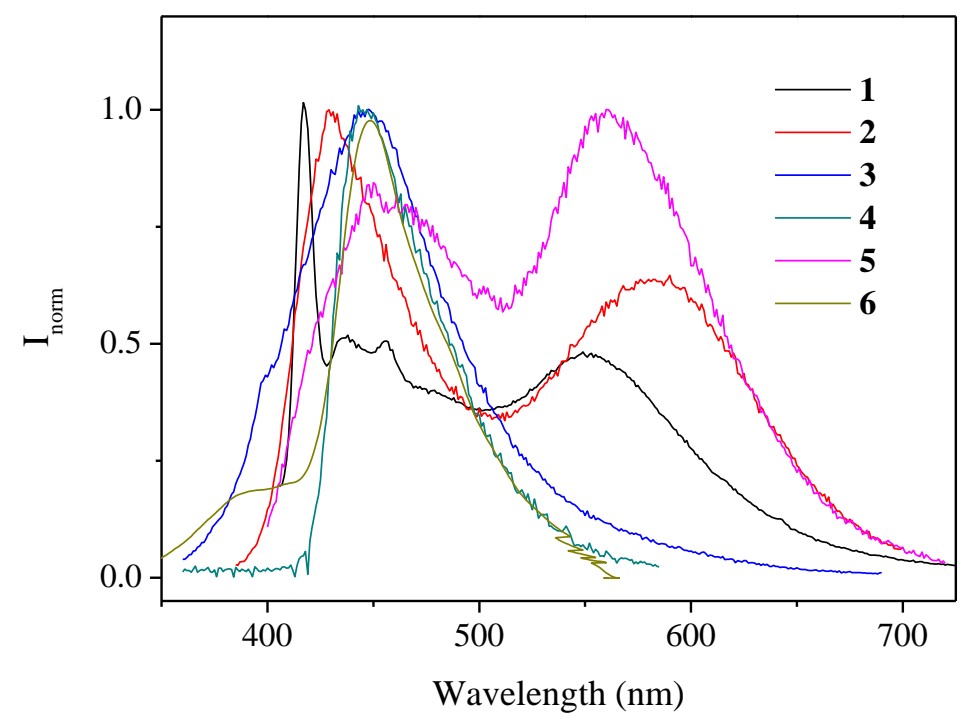

Figure 8. Emission spectra of $2.5 \times 10^{-5} \mathrm{M}$ solutions of complexes 1-6 in water

$$
\left(\lambda_{\text {exc }}=370 \mathrm{~nm}\right) \text {. }
$$

\section{Absorption and emission in solvents of different polarity}

It was observed that complexes $\mathbf{2}$ and $\mathbf{3}$ displayed different colours when dissolved in water and in chloroform. In order to check the effect of the solvents in the corresponding solutions, $1 \times 10^{-3} \mathrm{M}$ samples of complexes 2,3 and their triflate analogous 5 and $\mathbf{6}$ in solvents of different polarity were prepared and their absorption and emission spectra recorded. No solvent effect was observed by naked eye for $\mathbf{1}$ and 4 . As displayed in Figure 9, the solutions of $\mathbf{3}$ present a wide range of different colours, and for this, their solvatochromic behaviour and the corresponding spectroscopic properties and resulting package were investigated.

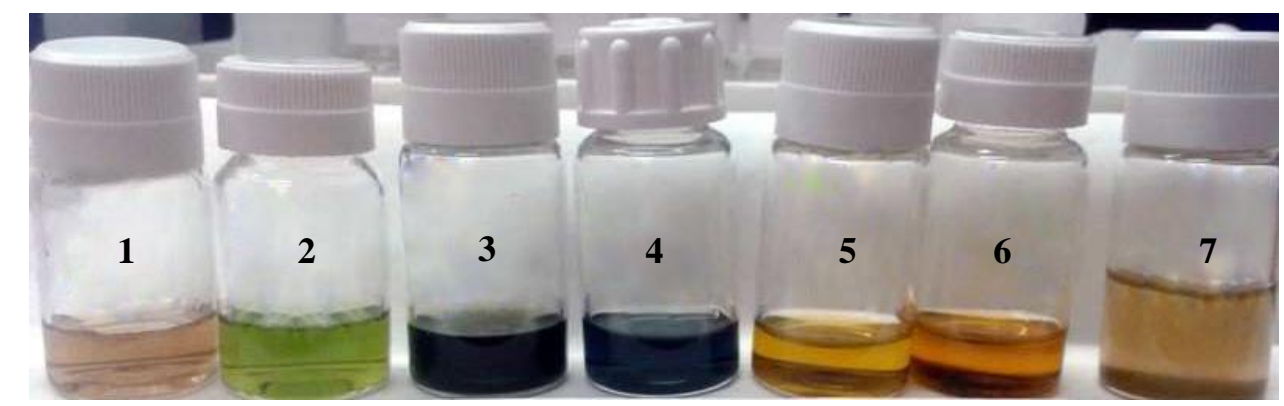

Figure 9. $1 \times 10^{-3} \mathrm{M}$ solutions of $\mathbf{3}$ in solvents of different polarity (1, water; 2, methanol; 3, acetonitrile; 4, chloroform; 5, THF; 6, toluene; 7, cyclohexane). 
Absorption and emission spectra were collected for freshly prepared samples in all different solvents and the multiparametric method of Kamlet and Taft, ${ }^{52}$ in which UVVis absorption and emission energies are correlated with different solvent properties according to equation 1 , was applied. ${ }^{53-57}$ In this equation, $\bar{v}_{0}$ is the value of the absorption and/or emission energies in a reference solvent (cyclohexane; $\alpha=\beta=\pi^{*}=$ 0 ), $\alpha$ is an index of the solvent's ability to act as a hydrogen-bond donor (or electron pair acceptor) toward a solute and $\beta$ is a measure of the ability of a bulk solvent to act as a hydrogen-bond acceptor (or electron-pair donor), $\pi^{*}$ is an index of the solvent polarity/polarizability which measures the solvent's ability to stabilize a neighbouring charge or dipole through non-specific dielectric interactions and $\delta$ is polarizability correction for different classes of solvent (aliphatic, aromatic or halogenated). Often, the contribution of $\delta$ is negligible leading to the simplified equation 2, from which the parameters $\mathrm{a}, \mathrm{b}$ and $\mathrm{p}$ (corresponding to the responses of the appropriate solute molecular property to the relevant solvent property) can be retrieved through a multiparametric fitting on various solvents. $\alpha, \beta$ and $\pi^{*}$ are tabulated values (Table S2).

$$
\begin{array}{ll}
\bar{v}=\bar{v}_{0}+a \alpha+b \beta+p\left(\pi^{*}+d \delta\right) & \text { Equation 1 } \\
\bar{v}=\bar{v}_{0}+a \alpha+b \beta+p \pi^{*} & \text { Equation 2 }
\end{array}
$$

The absorption band around $450 \mathrm{~nm}$ of compounds $\mathbf{2}$ and $\mathbf{3}$ in water is observed to be strongly dependent on solvent polarity (Table S3 and Figures 10 and S19). Interestingly, this band does not appear for triflate derivatives (5 and 6) in agreement with the previous XLCT assignment $\left(\mathrm{X}=\mathrm{I}^{-}\right)$and solvatochromic effect was not detected. A large negative solvatochromism (hypsochromic effect) is observed for $\mathbf{2}$ and $\mathbf{3}$ (62 nm and 65 $\mathrm{nm}$ respectively $\left.\left(\sim 155000 \mathrm{~cm}^{-1}\right)\right)$ due to a stabilization of the ground state in more polar solvents during the transition. Kamlet-Taft multiparametric fitting (Table 2 and Figures S19-S21) shows that the polarity/polarizability (measured by $\pi^{*}$ parameter) is the main effect on this hypsochromic shift (larger $p$ value), that means that the stabilization by $\mathrm{H}$ bonding of the ground state is less important and even less for the DAPTA derivative, 3. Nevertheless, the ability to establish or to accept H-bonds between solvent and solute is not negligible. In fact, both $a$ and $b$ values are positive, and indicate a stabilization of the ground state, increasing the energy of the transition. 


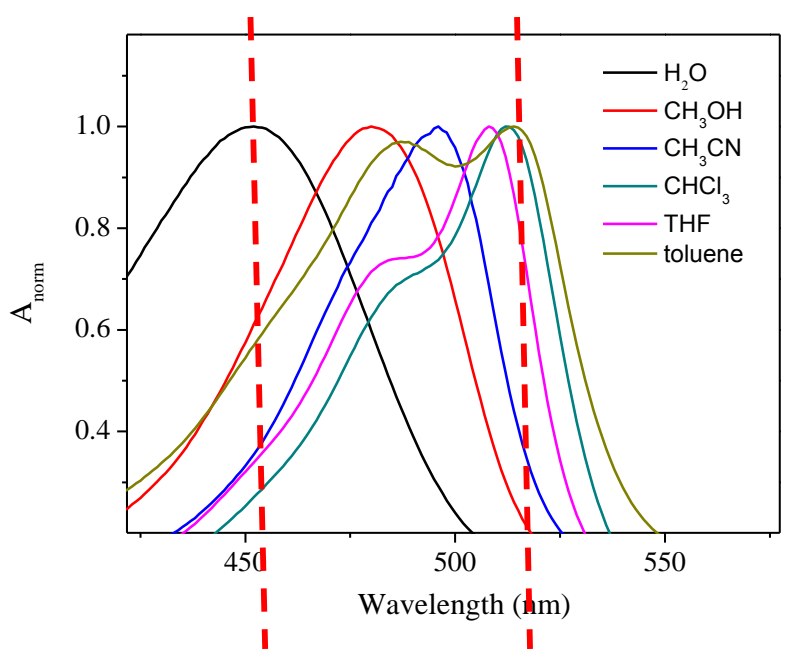

Figure 10. Normalized absorption spectra of complex 3 recorded in different solvents. Hypsochromic effect with increasing polarity (negative solvatochromism) is shown.

Table 2. $\mathrm{a}, \mathrm{b}, \mathrm{p}$ and $\overline{\mathrm{v}}_{0}$ values, in $\mathrm{cm}^{-1}$, as well as slope and correlation coefficients obtained from Kamlet-Taft multiparametric fitting of the absorption data.

\begin{tabular}{ccccccc}
\hline Compound & $\mathrm{A}$ & $\mathrm{b}$ & $\mathrm{p}$ & $\overline{\mathrm{v}}_{0}$ & slope & $\mathrm{r}^{2}$ \\
\hline $\mathbf{2}$ & 942 & 959 & 2537 & 17789 & 1 & 0.99 \\
$\mathbf{3}$ & 726 & 707 & 3288 & 17430 & 1 & 0.99 \\
\hline
\end{tabular}

Interesting findings may be retrieved from emission spectra recorded for all different solvents upon excitation at the lowest energy absorption band (ca. $370 \mathrm{~nm}$ ). Two different emission bands at $c a .450 \mathrm{~nm}$ and $550 \mathrm{~nm}$ were recorded for all complexes as exemplified for 2 in Figure 11 (see also Figures S22 and S23 for the other complexes). In the case of $\mathbf{2}$ and $\mathbf{5}$, the general observed trend is that the lowest energy emission band increases in intensity with the solvent polarity. In the less polar solvents as chloroform, THF, toluene and cyclohexane the band at 550-600 $\mathrm{nm}$ drastically disappears. By comparison with previous studies ${ }^{15,16}$ the broad emission shape of both bands seem to be assigned to emissive aggregates. The lowest energy emission band recorded in polar solvents may indicate the formation of larger structures in these media in agreement with NMR data. A particular case is the emission spectrum recorded in cyclohexane (less polar solvent) that displays a different profile with a vibronically structured shape (see Figure 11). This could be attributed to the emission of monomer, in agreement with previous works. ${ }^{15,16}$ 
Excitation spectra collected at the emission maxima display two different bands centred at ca. $350 \mathrm{~nm}$ (more apolar solvents) and an additional band $450 \mathrm{~nm}$ (only observed in more polar solvents) corresponding to absorption of the less and more aggregated samples (see Figure S24).

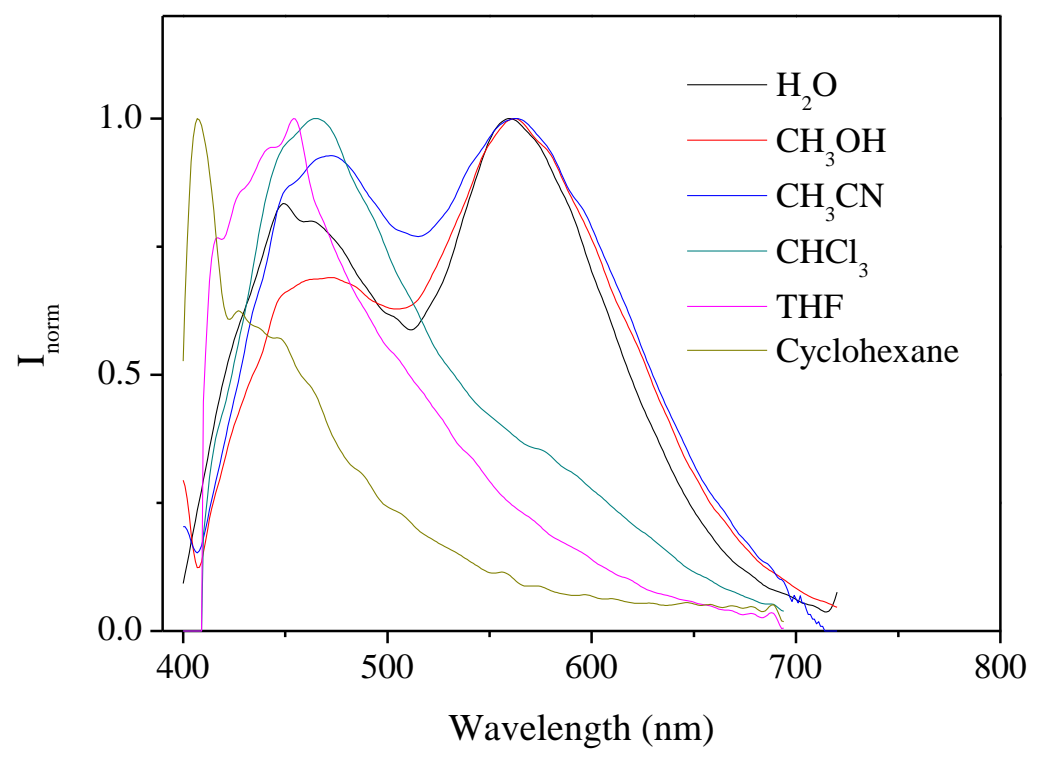

Figure 11. Normalized emission spectra of $5 \cdot 10^{-5} \mathrm{M}$ solutions of 2 in different solvents

$$
\left(\lambda_{\text {exc }}=370 \mathrm{~nm}\right) \text {. }
$$

No emission bands were displayed for $\mathbf{3}$ and $\mathbf{6}$ in less polar solvents upon excitation of the samples at $370 \mathrm{~nm}$ (absorption of larger aggregates). Excitation of these samples at the lower absorption wavelength $(c a .300 \mathrm{~nm})$ gives rise to emission bands centred at $c a .350 \mathrm{~nm}$ and $450 \mathrm{~nm}$. This fact is in agreement with the higher solubility of the DAPTA complexes with respect to the analogous PTA derivatives.

\section{Analysis of the samples with diferent solvents under microscopic techniques}

The dried samples were also observed under optical microscopy and SEM in order to correlate the morphology of the aggregates with the observed absorption and emission bands. No supramolecular structures could be detected for the samples prepared in cyclohexane, which together with the lack of the broad emission at 550-600 $\mathrm{nm}$, corroborates the fact that emissive aggregates are responsible for this emission. On the other hand, different topologies were detected in the remaining solvents, which means that in all cases supramolecular structures were obtained and that these different 
shapes can be correlated with the different spectroscopic emission patterns recorded (Figures 12 and S25-28).
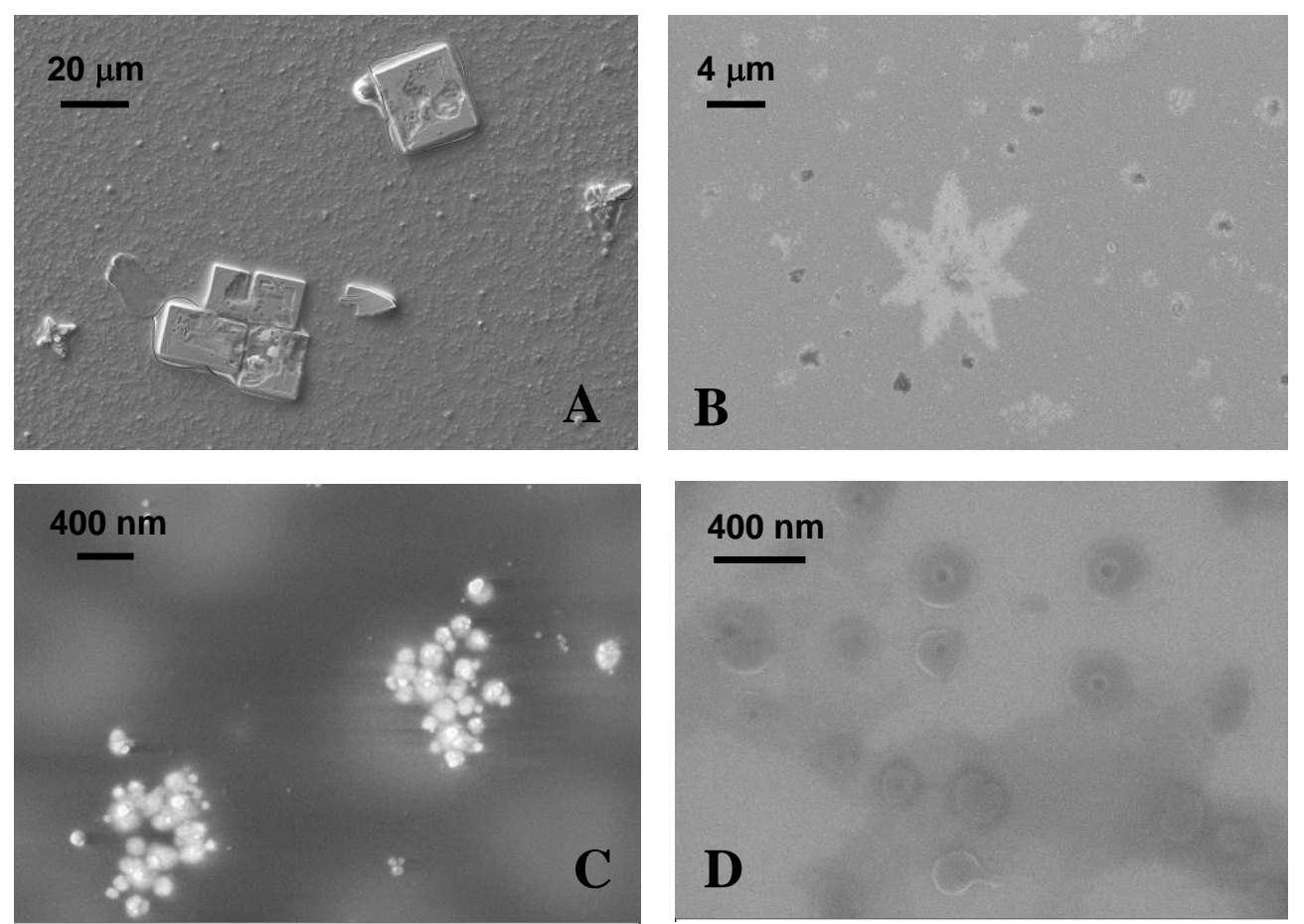

Figure 12. SEM images of dried samples of 5 in water (A), methanol (B), acetonitrile (C) and $\mathrm{CHCl}_{3}$ (D)

It is accepted in the literature that the presence of aurophilic interactions can produce long wavelength luminescent crystals that are responsive to changes in their environment. ${ }^{58,59,60}$ In particular, many gold crystalline complexes display solvo- or vapoluminescence that is a result of uptake solvent molecules into the solid phase. Nevertheless, to the best of our knowledge, this is the first report where it is shown how solvent promotes the formation of different supramolecular shapes of gold(I) alkynyl aurophilic aggregates. 


\section{Conclusions}

We have demonstrated how to modulate the resulting supramolecular morphology of gold(I) alkynyl complexes by the introduction of different modifications on the chemical structure and environment. The effect of the introduction of a positive charge let us to create rod-like structures when a cationic charge is located at the PTA phosphine (complex 1). This morphology completely changes to the formation of vesicles or reversed micelles when this charge is located on the pyridyl unit (complexes 2 and 3 ).

Changing the counterion from iodide to triflate determines a different supramolecular package giving rise to the formation of square-like assemblies (complexes $\mathbf{5}$ and $\mathbf{6}$ ) in water while the higher solubility of the triflate analogous of $\mathbf{1}$ (complex $\mathbf{4}$ ) precludes the formation of aggregates. Hence, we can modulate the formation of different types of 3D structures formed by the establishment of weak interactions between molecules (mainly aurophilic interactions).

The solutions of complexes $\mathbf{2}, \mathbf{3}, \mathbf{5}$ and $\mathbf{6}$ in different solvents let us to demonstrate that this parameter also affects the resulting supramolecular package as could be seen by the corresponding emission spectra and microscopy images. Moreover, Kamlet-Taft multiparametric analysis of XLCT absorption band of complexes $\mathbf{2}$ and $\mathbf{3}$ indicates that the observed negative solvatochromism in absorption is mainly due to polarity/polarizability effects while solvent polarity affects on the resulting emission of the aggregates. 


\section{Experimental Section}

\section{General procedures}

All manipulations have been performed under prepurified $\mathrm{N}_{2}$ using standard Schlenk techniques. All solvents have been distilled from appropriated drying agents. Commercial reagents 1,3,5-triaza-7-phosphatricyclo[3.3.1.13.7]decane (PTA, Aldrich 97\%), 3,7-diacetyl-1,3,7-triaza-5- phosphabicyclo[3.3.1]nonane (DAPTA, Aldrich 97\%), MeI (Aldrich, 99\%) and $\mathrm{MeCF}_{3} \mathrm{SO}_{3}$ (Aldrich, 99\%) have been used as received. Literature methods have been used to prepare N-methyl-4-ethynylpyridine iodide, ${ }^{60}$ $[\mathrm{AuCl}(\mathrm{PTA})],{ }^{61}[\mathrm{AuCl}(\mathrm{DAPTA})],{ }^{61}[\mathrm{Tl}(\mathrm{acac})]^{62}$ and $\left[\mathrm{Au}\left(\mathrm{C} \equiv \mathrm{C}-\mathrm{C}_{5} \mathrm{H}_{4} \mathrm{~N}\right)(\mathrm{PTA})\right] .{ }^{15}$ Similar procedure previously reported for N-methyl-4-ethynylpyridine iodide was used for the synthesis of N-methyl-4-ethynylpyridine triflate, ${ }^{63}$ but using $\mathrm{MeCF}_{3} \mathrm{SO}_{3}$ instead of MeI.

\section{Physical measurements}

Infrared spectra have been recorded on a FT-IR 520 Nicolet Spectrophotometer. ${ }^{1} \mathrm{H}$ $\operatorname{NMR}(\delta(\mathrm{TMS})=0.0 \mathrm{ppm}),{ }^{31} \mathrm{P}\left\{{ }^{1} \mathrm{H}\right\}-\mathrm{NMR}\left(\delta\left(85 \% \mathrm{H}_{3} \mathrm{PO}_{4}\right)=0.0 \mathrm{ppm}\right)$ spectra have been obtained on a Varian Mercury 400, Bruker 400 and Bruker DMX 500. ES(+) mass spectra has been recorded on a Fisons VG Quatro spectrometer. Absorption spectra were recorded on a Varian Cary 100 Bio UV- spectrophotometer and emission spectra on a Horiba-Jobin-Ybon SPEX Fluorolog 3.22 and Nanolog spectrofluorimeters. Microspectrofluorimetry measurements have been obtained with a MicroSPEX instrument where the Spex Fluorog apparatus 3.22 is connected to an Olympus BX51 M confocal microscope (Universidade Nova de Lisboa). Fluorescence microscopy have been recorded on an Axioplan 2ie Zeiss imaging microscope equipped with a NikonDXM1200F digital camera (Universidade Nova de Lisboa) and Leica DMIRB fluorescence microscope (Universitat de Barcelona). Optical microscopy was carried out on an Olympus BX51. Scanning electron microscopy has been carried out a $5 \mathrm{kV}$ using a Neon40 Crossbeam Station (Zeiss) equipped with a field emission gun. CryoTransmission electron microscopy measurements have been obtained with a Tecnai G2 F20 (FEI) 200kV FEG TEM cryomicroscope. A Horiba Scientific Nanoparticle Analyzer SZ-100 (Universidade Nova de Lisboa) operating at $25{ }^{\circ} \mathrm{C}$ was used to obtain the dynamic light scattering (DLS) measurements. 


\section{Preparation of the samples}

Optic and fluorescence microscopy measurements

$1 \mathrm{mg}$ of each compound was dissolved in $5 \mathrm{ml}$ of each solvent. To make the measurements, a drop of each solution was placed into a microscope slide and evaporated to dryness.

\section{SEM measurements}

$4 \times 10^{-4} \mathrm{M}$ solutions of the complexes were used. A drop of each solution was deposited into a silicon plate and evaporated to dryness in contact with air. This process was carried out in the same way for all the different solvents.

\section{Polarity effect studies.}

The solvents used were double-distilled water, methanol p.a. (Fluka), acetonitrile p.a. (Fluka), THF (appropriate drying agents), chloroform p.a. (Fluka), toluene (appropriate drying agents) and cyclohexane p.a. (Panreac).

To prepare solutions of $\mathbf{2 , 3}$, and $\mathbf{5 , 6}, 1 \mathrm{mg}$ of each compound was dissolved in $5 \mathrm{ml}$ of each solvent, then the mother solutions were diluted to half concentration and the spectra were recorded. All measurements were made immediately after solution preparation as the coloring of these varies with time.

Synthesis of [Au(acac)(PTA)] (1a). Solid Tl(acac) (76 mg, $0.25 \mathrm{mmol})$ was added to a solution of [AuCl(PTA)] (100 mg, $0.25 \mathrm{mmol})$ in acetone $(10 \mathrm{ml})$. After four days of stirring at room temperature, the resulting white suspension was filtered. The solution was concentrated to $c a .5 \mathrm{ml}$ and $n$-hexane $(10 \mathrm{ml})$ was added to precipitate $[\mathrm{Au}(\mathrm{acac})(\mathrm{PTA})]$ as a white solid which was filtered off and dried in vacuum. Yield: 71 $\%(82 \mathrm{mg}) .{ }^{1} \mathrm{H}-\mathrm{NMR}\left(400 \mathrm{MHz}, \mathrm{CDCl}_{3}\right)$ : 4.60-4.46 (AB q, $\left.J=12 \mathrm{~Hz}, 6 \mathrm{H}, \mathrm{N}-\mathrm{CH}_{2}-\mathrm{N}\right)$, $4.28\left(\mathrm{~s}, 6 \mathrm{H}, \mathrm{N}-\mathrm{CH}_{2}-\mathrm{P}\right), 2.25-2.12\left(\mathrm{~m}, 8 \mathrm{H}, \mathrm{CH}_{3}-(\mathrm{CO})-\mathrm{CH}_{2}-(\mathrm{CO})-\mathrm{CH}_{3}\right) .{ }^{31} \mathrm{P}\left\{{ }^{1} \mathrm{H}\right\}-\mathrm{NMR}$ $\left(162 \mathrm{MHz}, \mathrm{CDCl}_{3}\right)$ : -45.1 . IR $\left(\mathrm{KBr}, \mathrm{cm}^{-1}\right): 1635(\mathrm{C}=\mathrm{O})$.

Synthesis of [Au(acac)(DAPTA)] (2a). Solid Tl(acac) (90 mg, $0.30 \mathrm{mmol}$ ) was added to a solution of [AuCl(DAPTA)] $(120 \mathrm{mg}, 0.30 \mathrm{mmol})$ in acetone $(10 \mathrm{ml})$. After four days of stirring at room temperature, the white suspension was filtered. The resulting solution was concentrated to $c a .5 \mathrm{ml}$ and $n$-hexane $(10 \mathrm{ml})$ was added to precipitate $[\mathrm{Au}(\mathrm{acac})(\mathrm{DAPTA})]$ as a white solid which was filtered off and dried in vacuum. Yield: 
$73 \%(99 \mathrm{mg}) .{ }^{1} \mathrm{H}-\mathrm{NMR}\left(400 \mathrm{MHz}, \mathrm{CDCl}_{3}\right): 5.80\left(\mathrm{~d}, J=20.0 \mathrm{~Hz}, 1 \mathrm{H}, \mathrm{N}-\mathrm{CH}_{2}-\mathrm{N}\right), 5.60$ $\left(\mathrm{dd}, J=20.0 / 12.0 \mathrm{~Hz}, 1 \mathrm{H}, \mathrm{N}-\mathrm{CH}_{2}-\mathrm{P}\right), 4.96\left(\mathrm{~d}, J=16.0 \mathrm{~Hz}, 1 \mathrm{H}, \mathrm{N}-\mathrm{CH} H_{2}-\mathrm{N}\right), 4.80-4.60$ $\left(\mathrm{m}, 2 \mathrm{H}, \mathrm{N}-\mathrm{CH}_{2}-\mathrm{P}+\mathrm{N}-\mathrm{CH}_{2}-\mathrm{N}\right), 4.15\left(\mathrm{dt}, J=20.0 / 4.0,1 \mathrm{H}, \mathrm{N}-\mathrm{CH}_{2}-\mathrm{P}\right), 4.07(\mathrm{~d}, J=20.0$ $\mathrm{Hz}, 1 \mathrm{H}, \mathrm{N}-\mathrm{CH}_{2}-\mathrm{N}$ ), 3.87 (s, 2H, N-CH$-\mathrm{P}$ ), 3.57 (dt, $J=20.0 / 4.0 \mathrm{~Hz}, 1 \mathrm{H}, \mathrm{N}-\mathrm{CH}_{2}-\mathrm{P}$ ), $3.85\left(\mathrm{~s}, 3 \mathrm{H}, \mathrm{N}-\mathrm{CH}_{3}\right), 1.85$ (s, 6H, CO-CH$\left.)_{3}\right), 2.25-2.12$ (m, 8H, $\mathrm{CH}_{3}-(\mathrm{CO})-\mathrm{CH}_{2}-(\mathrm{CO})-$ $\left.\mathrm{CH}_{3}\right) .{ }^{31} \mathrm{P}\left\{{ }^{1} \mathrm{H}\right\}-\mathrm{NMR}\left(162 \mathrm{MHz}, \mathrm{CDCl}_{3}\right):-48.3$. IR $\left(\mathrm{KBr}, \mathrm{cm}^{-1}\right): 1675(\mathrm{C}=\mathrm{O})$.

Synthesis of $\left[\mathrm{Au}\left(\mathbf{C} \equiv \mathbf{C}-\mathbf{C}_{5} \mathbf{H}_{4} \mathbf{N}\right)\left(\mathbf{C H}_{3}\right.\right.$ PTA $\left.)\right] \mathbf{I}(\mathbf{1}) \cdot \mathrm{CH}_{3} \mathrm{I}(0.12 \mathrm{ml}, 0.19 \mathrm{mmol})$ was added dropwise to a solution of $\left[\mathrm{Au}\left(\mathrm{C} \equiv \mathrm{C}-\mathrm{C}_{5} \mathrm{H}_{4} \mathrm{~N}\right)(\mathrm{PTA})\right](60 \mathrm{mg}, 0.13 \mathrm{mmol})$ in $\mathrm{CH}_{2} \mathrm{Cl}_{2}(10$ $\mathrm{ml})$ at $-40^{\circ} \mathrm{C}$. The suspension was allowed to warm until room temperature for 4 hours. The resulting pale yellow solution was concentrated to $c a .5 \mathrm{ml}$, and diethyl ether (10 $\mathrm{ml}$ ) was added to precipitate a pale yellow solid. Yield: $80 \%$ (73 mg). ${ }^{1} \mathrm{H}-\mathrm{NMR}$ (400 $\left.\mathrm{MHz}, \mathrm{D}_{2} \mathrm{O}, \mathrm{ppm}\right): 8.46\left(\mathrm{~d}, J=8.0 \mathrm{~Hz}, 2 \mathrm{H}, \mathrm{H}_{\alpha-\mathrm{pyr}}\right), 7.41\left(\mathrm{~d}, J=8.0 \mathrm{~Hz}, 2 \mathrm{H}, \mathrm{H}_{\beta-\mathrm{pyr}}\right), 5.08$ $4.90\left(\mathrm{AB}\right.$ m, 4H, N-CH${ }_{2}-\mathrm{N}^{+}$), 4.69-4.59 (AB m, 2H, N-CH$-\mathrm{N}$ ), 4.56-4.44 (m, 2H, P$\mathrm{CH}_{2}-\mathrm{N}^{+}$), 4.33-4.06 (AB, m, 4H, N-CH2-P), 2.86 (s, 3H, N $\left.{ }^{+}-\mathrm{CH}_{3}\right) .{ }^{31} \mathrm{P}-\mathrm{NMR}(162 \mathrm{MHz}$, $\left.\mathrm{D}_{2} \mathrm{O}, \mathrm{ppm}\right):-57.2$. IR $\left(\mathrm{KBr}, \mathrm{cm}^{-1}\right): 3425\left(\mathrm{C}-\mathrm{H}\left(\mathrm{CH}_{3}\right)\right), 2100(\mathrm{C} \equiv \mathrm{C}), 1664(\mathrm{C}=\mathrm{N})$. ES-MS (+) $m / z: 471.10$ ([M]+, calc.: 471.10). Elemental Analyses Calc. \%: C: 29.33, H, 3.77, N: 9.12; Found \%: C: 29.42, H: 3.80, N: 9.31.

Synthesis of $\left[\mathbf{A u}\left(\mathbf{C} \equiv \mathbf{C}-\mathbf{C}_{5} \mathbf{H}_{4} \mathbf{N}-\mathbf{C H}_{3}\right)(\mathbf{P T A})\right] \mathbf{I}(\mathbf{2})$. Solid [Au(acac)(PTA)] (40 mg, 0.08 mmol) was added to a solution of N-methyl-4-ethynylpyridine $(10 \mathrm{mg}, 0.08 \mathrm{mmol})$ in THF (10 ml). After 1 hour of stirring at room temperature, the resulting red solution was concentrated, and diethyl ether $(10 \mathrm{ml})$ was added to precipitate a dark red solid. Yield: $75 \%$ (30 mg). ${ }^{1} \mathrm{H}-\mathrm{NMR}\left(400 \mathrm{MHz}, \mathrm{D}_{2} \mathrm{O}\right): 8.10$ (d, $\left.J=12.0 \mathrm{~Hz}, 2 \mathrm{H}, \mathrm{H}_{\alpha-\mathrm{pyr}}\right), 7.61$ (d, $J=$ $12.0 \mathrm{~Hz}, 2 \mathrm{H}, \mathrm{H}_{\beta-\text { pyr }}$ ), 4.67-4.50 (AB q, $\left.J=16.0 \mathrm{~Hz}, 6 \mathrm{H}, \mathrm{N}-\mathrm{CH}_{2}-\mathrm{N}\right), 4.37$ (s, 6H, N-CH $2^{-}$ P), $3.88\left(\mathrm{~s}, 3 \mathrm{H}, \mathrm{CH}_{3}\right) .{ }^{31} \mathrm{P}-\mathrm{NMR}\left(162 \mathrm{MHz}, \mathrm{CDCl}_{3}, \mathrm{ppm}\right):-48.2 \mathrm{IR}\left(\mathrm{KBr}, \mathrm{cm}^{-1}\right): 3425$ (C-H), 2104 (C三C), $1640(\mathrm{C}=\mathrm{N})$. ESI-MS (+) m/z: 471.10 ([M]+, calc.: 471.10). Elemental Analyses Calc. \%: C: 29.33, H, 3.77, N: 9.12; Found \%: C: 29.44, H: 3.81, N: 9.28.

Synthesis of $\left[\mathbf{A u}\left(\mathbf{C} \equiv \mathbf{C}-\mathbf{C}_{5} \mathbf{H}_{\mathbf{4}} \mathbf{N}-\mathbf{C H}_{3}\right)(\right.$ DAPTA)]I (3). Solid [Au(acac)(DAPTA)] (44 $\mathrm{mg}, 0.09 \mathrm{mmol}$ ) was added to a solution of $\mathrm{N}$-methyl-4-ethynylpyridine (10 mg, 0.09 $\mathrm{mmol})$ in THF $(10 \mathrm{ml})$. After 1 hour of stirring at room temperature, the resulting red solution was concentrated, and diethyl ether $(10 \mathrm{ml})$ was added to precipitate a dark red 
solid. Yield: $50 \%$ (23 mg). ${ }^{1} \mathrm{H}-\mathrm{NMR}\left(400 \mathrm{MHz}, \mathrm{D}_{2} \mathrm{O}\right): 8.80$ (d, $J=12.0 \mathrm{~Hz}, 2 \mathrm{H}, \mathrm{H}_{\alpha-p y r}$ ), $7.70\left(\mathrm{~d}, J=12.0 \mathrm{~Hz}, 2 \mathrm{H}, \mathrm{H}_{\beta \text {-pyr }}\right), 5.65\left(\mathrm{~d}, J=20.0 \mathrm{~Hz}, 1 \mathrm{H}, \mathrm{N}-\mathrm{CH}_{2}-\mathrm{N}\right), 5.40(\mathrm{dd}, J=$ 20.0/12.0 Hz, 1H, N-CH $\left.H_{2}-\mathrm{P}\right), 5.10\left(\mathrm{~d}, J=16.0 \mathrm{~Hz}, 1 \mathrm{H}, \mathrm{N}-\mathrm{CH}_{2}-\mathrm{N}\right), 4.70-3.88(\mathrm{~m}, 7 \mathrm{H}, \mathrm{N}-$ $\left.\mathrm{CH}_{2}-\mathrm{P}+\mathrm{N}-\mathrm{CH}_{2}-\mathrm{N}+\mathrm{N}-\mathrm{CH}_{2}-\mathrm{P}+\mathrm{N}-\mathrm{CH}_{2}-\mathrm{N}+\mathrm{N}-\mathrm{CH}_{2}-\mathrm{P}+\mathrm{N}-\mathrm{CH}_{2}-\mathrm{P}\right), 3.76$ (s, 3H, N$\left.\mathrm{CH}_{3}\right), 1.85$ (s, 6H, CO-CH$) .{ }^{31} \mathrm{P}\left\{{ }^{1} \mathrm{H}\right\}-\mathrm{NMR}\left(162 \mathrm{MHz}, \mathrm{CDCl}_{3}, \mathrm{ppm}\right)$ : -17.2. IR (KBr, $\left.\mathrm{cm}^{-1}\right): 3430(\mathrm{C}-\mathrm{H}), 2100(\mathrm{C}=\mathrm{C}), 1937(\mathrm{C}=\mathrm{O}), 1634(\mathrm{C}=\mathrm{N})$. ESI-MS (+) $m / z: 543.12$ ([M]+, calc.: 543.12). Elemental Analyses Calc. \%: C: 30.46, H, 3.46, N: 8.36; Found $\%:$ C: $30.49, \mathrm{H}: 3.49, \mathrm{~N}: 8.41$.

Synthesis of $\left[\mathrm{Au}\left(\mathbf{C} \equiv \mathbf{C}-\mathbf{C}_{\mathbf{5}} \mathbf{H}_{\mathbf{4}} \mathbf{N}\right)\left(\mathbf{C H}_{\mathbf{3}} \mathbf{P T A}\right)\right]\left(\mathbf{C F}_{\mathbf{3}} \mathbf{S O}_{\mathbf{3}}\right) \quad(\mathbf{4}) . \mathrm{CH}_{3} \mathrm{CF}_{3} \mathrm{SO}_{3} \quad(4.1 \mu 1,0.36$ mmol) was added dropwise to a solution of $\left[\mathrm{Au}\left(\mathrm{C} \equiv \mathrm{C}-\mathrm{C}_{5} \mathrm{H}_{4} \mathrm{~N}\right)(\mathrm{PTA})\right](11 \mathrm{mg}, 0.24$ mmol) in $\mathrm{CH}_{2} \mathrm{Cl}_{2}(10 \mathrm{ml})$ at $-40^{\circ} \mathrm{C}$. The suspension was allowed to warm until room temperature for 4 hours. The resulting pale yellow solution was concentrated to $c a$. 5 $\mathrm{ml}$, and diethyl ether $(10 \mathrm{ml})$ was added to precipitate a yellow solid. Yield: 80\% (15 mg). ${ }^{1} \mathrm{H}-\mathrm{NMR}$ (400 MHz, $\left.\mathrm{D}_{2} \mathrm{O}, \mathrm{ppm}\right): 8.60$ (d, $J=6.4 \mathrm{~Hz}, 2 \mathrm{H}, \mathrm{H}_{\alpha}$-pyr), 7.85 (d, $J=6.4$ $\mathrm{Hz}, 2 \mathrm{H}, \mathrm{H}_{\beta}$-pyr), 5.10-4.92 (AB m, 4H, N-CH $\left.\mathrm{H}_{2}-\mathrm{N}^{+}\right), 4.69-4.59\left(\mathrm{AB} \mathrm{m}, 2 \mathrm{H}, \mathrm{N}-\mathrm{CH}_{2}-\mathrm{N}\right)$, 4.54-4.45 (m, 2H, P-CH $\mathrm{CH}_{2}-\mathrm{N}^{+}$), 4.34-4.12 ( $\left.\mathrm{AB}, \mathrm{m}, 4 \mathrm{H}, \mathrm{N}-\mathrm{CH}_{2}-\mathrm{P}\right), 2.89$ (s, 3H, N ${ }^{+}-\mathrm{CH}_{3}$ ). ${ }^{31} \mathrm{P}\left\{{ }^{1} \mathrm{H}\right\}$-NMR (162 MHz, $\left.\mathrm{D}_{2} \mathrm{O}, \mathrm{ppm}\right):-43.6 . \mathrm{IR}\left(\mathrm{KBr}, \mathrm{cm}^{-1}\right): 3433\left(\mathrm{C}-\mathrm{H}\left(\mathrm{CH}_{3}\right)\right), 2113$ $(\mathrm{C} \equiv \mathrm{C}), 1629(\mathrm{C}=\mathrm{N}), 1264(\mathrm{C}-\mathrm{F})$. ES-MS (+) m/z: $471.10([\mathrm{M}]+$, calc.: 471.10). Elemental Analyses Calc. \%: C: 30.43, H, 3.55, N: 7.89, S: 4.51; Found \%: C: 3.59, H: 3.45, N: 7.80, S: 4.70.

\section{Synthesis of $\left[\mathrm{Au}\left(\mathrm{C} \equiv \mathrm{C}-\mathrm{C}_{5} \mathrm{H}_{4} \mathrm{~N}-\mathrm{CH}_{3}\right)(\mathrm{PTA})\right]\left(\mathrm{CF}_{3} \mathrm{SO}_{3}\right)(5)$.}

Solid [Au(acac)(PTA)] (60 mg, $0.13 \mathrm{mmol})$ was added to a solution of N-methyl-4ethynylpyridine triflate $(43 \mathrm{mg}, 0.15 \mathrm{mmol})$ in THF $(10 \mathrm{ml})$. After 1 hour of stirring at room temperature the solution was concentrated to half volume and diethyl ether (10 $\mathrm{ml}$ ) was added to precipitate a dark green solid. Yield: $68 \%(55 \mathrm{mg}) .{ }^{1} \mathrm{H}$ NMR (CD $\left.\mathrm{CD}_{3} \mathrm{OD}, 400 \mathrm{MHz}, \mathrm{ppm}\right): 8.53$ (d, $\left.J=5.9 \mathrm{~Hz}, 2 \mathrm{H}, \mathrm{H}_{\alpha-\mathrm{pyr}}\right), 7.87$ (d, $J=6.2 \mathrm{~Hz}, 2 \mathrm{H}, \mathrm{H}_{\beta-}$ pyr $)$, 4.71-3.85 (m, 15H, N-CH $\left.-\mathrm{N}+\mathrm{N}-\mathrm{CH}_{2}-\mathrm{P}+\mathrm{N}-\mathrm{CH}_{3}\right) .{ }^{31} \mathrm{P}\left\{{ }^{1} \mathrm{H}\right\}-\mathrm{NMR}(162 \mathrm{MHz}$, $\left.\mathrm{CD}_{3} \mathrm{OD}, \mathrm{ppm}\right)$ : -27.0. IR $\left(\mathrm{KBr}, \mathrm{cm}^{-1}\right): 2109(\mathrm{C} \equiv \mathrm{C}), 1636(\mathrm{C}=\mathrm{N}) . \operatorname{ESI}-\mathrm{MS}(+) \mathrm{m} / \mathrm{z}$ : $471.10\left([\mathrm{M}]^{+}\right.$calc: 471.10). Elemental Analyses Calc. \%: C: 30.43, H, 3.55, N: 7.89, S: 4.51; Found \%: C: 30.52, H: 3.60, N: 7.81, S: 4.67. 


\section{Synthesis of $\left[\mathrm{Au}\left(\mathrm{C} \equiv \mathrm{C}-\mathrm{C}_{5} \mathrm{H}_{4} \mathrm{~N}-\mathrm{CH}_{3}\right)(\mathrm{DAPTA})\right]\left(\mathrm{CF}_{3} \mathrm{SO}_{3}\right)(6)$.}

Solid [Au(acac)(DAPTA)] (25 mg, $0.05 \mathrm{mmol})$ was added to a solution of N-methyl-4ethynylpyridine triflate $(15 \mathrm{mg}, 0.05 \mathrm{mmol})$ in THF $(5 \mathrm{ml})$. After 1 hour of stirring at room temperature the solution was concentrated to half volume and diethyl ether (10 $\mathrm{ml}$ ) was added to precipitate a dark green solid. Yield: $70 \%(22 \mathrm{mg}) .{ }^{1} \mathrm{H}$ NMR (CD3OD, $400 \mathrm{MHz}, \mathrm{ppm}): 8.64$ (d, $J=6.5 \mathrm{~Hz}, 2 \mathrm{H}, \mathrm{H}_{\alpha-\mathrm{pyr}}$ ), 7.79 (d, $J=6.6 \mathrm{~Hz}, 2 \mathrm{H}, \mathrm{H}_{\beta-}$ pyr $), 5.71\left(\mathrm{~d}, J=13.9 \mathrm{~Hz}, 1 \mathrm{H}, \mathrm{N}-\mathrm{CH}_{2}-\mathrm{N}\right), 5.54\left(\mathrm{~m}, 1 \mathrm{H}, \mathrm{N}-\mathrm{CH}_{2}-\mathrm{P}\right), 5.08(\mathrm{~d}, J=14.7$ $\left.\mathrm{Hz}, 1 \mathrm{H}, \mathrm{N}-\mathrm{CH}_{2}-\mathrm{N}\right), 4.79-4.69\left(\mathrm{~m}, 2 \mathrm{H}, \mathrm{N}-\mathrm{CH}_{2}-\mathrm{P}+\mathrm{N}-\mathrm{CH}_{2}-\mathrm{N}\right), 4.51-3.68(\mathrm{~m}, 8 \mathrm{H}, \mathrm{N}-$ $\left.\mathrm{CH}_{2}-\mathrm{P}(1 \mathrm{H})+\mathrm{N}-\mathrm{CH} 2-\mathrm{N}(1 \mathrm{H}), \mathrm{N}-\mathrm{CH}_{2}-\mathrm{P}(2 \mathrm{H})+\mathrm{N}-\mathrm{CH}_{2}-\mathrm{P}(1 \mathrm{H})+\mathrm{N}-\mathrm{CH}_{3}(3 \mathrm{H})\right), 2.10$ (m, $\left.6 \mathrm{H}, \mathrm{CO}-\mathrm{CH}_{3}\right) .{ }^{31} \mathrm{P}\left\{{ }^{1} \mathrm{H}\right\}-\mathrm{NMR}(162 \mathrm{MHz}, \mathrm{CD} 3 \mathrm{OD}, \mathrm{ppm}):-17.8$. IR $\left(\mathrm{KBr}, \mathrm{cm}^{-1}\right): 2116$ $(\mathrm{C} \equiv \mathrm{C}), 1635(\mathrm{C}=\mathrm{N}) . \mathrm{ESI}-\mathrm{MS}(+): \mathrm{m} / \mathrm{z}: 543.12$ ([M]+, calc: 543.12). Elemental Analyses Calc. \%: C: 31.22, H, 3.35, N: 8.09, S: 4.63; Found \%: C: 30.97, H: 3.45, N: 7.95, S: 4.61. 


\section{Supporting Information Available}

Experimental Section; HR-ESI(+) mass spectrum of complex 1 (Figure S1); HR-ESI(+) mass spectrum of complex 2 (Figure S2); HR-ESI(+) mass spectrum of complex 3 (Figure S3); ${ }^{1} \mathrm{H}-\mathrm{NMR}$ spectrum of 2 in $\mathrm{D}_{2} \mathrm{O}$ (Figure $\mathrm{S} 4$ ); ${ }^{1} \mathrm{H}-\mathrm{NMR}$ spectrum of $\mathbf{3}$ in $\mathrm{D}_{2} \mathrm{O}$ (Figure S5); ${ }^{1} \mathrm{H}-\mathrm{NMR}$ spectrum of 2 in $\mathrm{CDCl}_{3}$ (Figure S6); ${ }^{1} \mathrm{H}$-NMR spectrum of $\mathbf{3}$ in $\mathrm{CDCl}_{3}$ (Figure S7); SEM images of dried samples of $\mathbf{2}$ (up) and $\mathbf{3}$ (bottom) (Figure S8); $\mathrm{Z}$ potential values measured for $5 \times 10^{-5} \mathrm{M}$ solutions of $\mathbf{2}$ and $\mathbf{3}$ in water by DLS measurements (Figure S9); ${ }^{1} \mathrm{H}-\mathrm{NMR}$ spectrum 4 in water (Figure S10); HR-ESI(+) mass spectrum of complex 5 (Figure S11); HR-ESI(+) mass spectrum of complex 6 (Figure S12); Optical microscopy images of aqueous dried samples of 5 (left) and 6 (right) (Figure S13); SEM images of aqueous dried samples of 5 (up) and 6 (bottom) (Figure $\mathrm{S} 14)$; DRX of $\left[\mathrm{Au}\left(\mathrm{C} \equiv \mathrm{C}-\mathrm{C}_{5} \mathrm{H}_{4} \mathrm{~N}-\mathrm{CH}_{3}\right)(\mathrm{PTA})\right] \mathrm{I}, 2$, (left) and $\left[\mathrm{Au}\left(\mathrm{C} \equiv \mathrm{C}-\mathrm{C}_{5} \mathrm{H}_{4} \mathrm{~N}-\right.\right.$ $\left.\left.\mathrm{CH}_{3}\right)(\mathrm{PTA})\right]\left(\mathrm{CF}_{3} \mathrm{SO}_{3}\right), 5$ (right) (Figure $\mathrm{S} 15$ ); Absorption spectra of $5 \times 10^{-5} \mathrm{M}$ solutions of complexes 1-6 in water (Figure S16); Absorption spectra of freshly prepared ca. $1 \times 10^{-4} \mathrm{M}$ solution (solid line) and after 2 days (red line) of 2 in water (Figure S17); Hypsochromic effect with increasing polarity (negative solvatochromism) displayed in absorption spectra of complex 2 (Figure S18); Plot of $\bar{v}_{0 \exp }$ vs. $\bar{v}_{0 \text { calc }}$ for absorption data of compound 3 (Figure S19); Plot of $\bar{v}_{0 \exp }$ vs. $\bar{v}_{0 \text { calc }}$ for absorption data of compound 2 (Figure S20); Normalized emission spectra of $\mathbf{3}$ in different solvents (Figure S21); Normalized emission spectra of $\mathbf{4}$ in different solvents $\left(\lambda_{\text {exc }}=370 \mathrm{~nm}\right)$ (Figure S22); Normalized emission spectra of 5 in different solvents $\left(\lambda_{\text {exc }}=300 \mathrm{~nm}\right)$ (Figure S23); Normalized excitation spectra of $\mathbf{2}$ in different solvents (Figure S24); Optical microscopy images of $\mathbf{2}$ in water (A), methanol (B), acetonitrile (C) and $\mathrm{CHCl}_{3}$ (D) (Figure S25); Optical microscopy images of $\mathbf{3}$ in water (A), methanol (B), acetonitrile (C) and $\mathrm{CHCl}_{3}$ (D) (Figure S26); Optical microscopy images of 5 in water (A), methanol (B), acetonitrile (C) and $\mathrm{CHCl}_{3}$ (D) (Figure S27); Optical microscopy images of 6 in water (A), methanol (B), acetonitrile (C) and $\mathrm{CHCl}_{3}$ (D) (Figure S28); Synthesis of N-methyl-4-ethynylpyridinum iodide (Scheme S1); Synthesis of N-methyl-4ethynylpyridinum triflate (Scheme S2); Synthesis of the N-methyl-4-ethynylpyridinum perchlorate derivatives (Scheme S3); Absorption and emission $\left(\lambda_{\mathrm{exc}}=370 \mathrm{~nm}\right)$ data of complexes 1-6 in water (Table S1); $\alpha, \beta, \pi^{*}$ parameters for the solvents used (Table S2); Absorption data of the XLCT band of $\mathbf{2}$ and $\mathbf{3}$ in different solvents (Table S3). 


\section{Acknowledgements}

The support and sponsorship provided by COST Action CM1005 is acknowledged. Authors are also grateful to the Ministerio de Ciencia e Innovación of Spain (Project ENE2012-36368). This work was also supported by the Associated Laboratory for Sustainable Chemistry- Clean Processes and Technologies- LAQV which is financed by national funds from FCT/MEC (UID/QUI/50006/2013) and co-financed by the ERDF under the PT2020 Partnership Agreement (POCI-01-0145-FEDER-007265). J.Ll. is Serra Húnter Fellow and is grateful to ICREA Academia program. This research was supported by a Marie Curie Intra European Fellowship within the 7th European Community Framework Programme (R.G.). 


\section{References}

${ }^{1}$ S. Gupta, A. Saxena, MRS Bulletin 2014, 39, 266.

2 D. Massiot, R.J. Messinger, S. Cadars, M. Deschamps, V. Montouillout, N. Pellerin,

E. Veron, M. Allix, P. Florian, F. Fayon, Acc. Chem. Res. 2013, 46, 1975.

${ }^{3}$ X. Zou, H. Ren, G. Zhu, Chem. Commun. 2013, 49, 3911.

${ }^{4}$ A.G. Evans, J.W. Hutchinson, N.A. Fleck, M.F. Ashby, Wadley, H.N.G. Prog. Mater. Sci. 2001, 46, 309.

${ }^{5}$ M.J. Mayoral Muñoz, G. Fernández, Chem. Sci. 2012, 3, 1395.

${ }^{6}$ E. Y.-H. Hong, H.-L. Wong, V.W.-W. Yam, Chem Commun. 2014, 50, 13272.

${ }^{7}$ R.A. Bilbeisi, J.-C. Olsen, L.J. Charbonnière, A.Trabolsi, Inorg. Chim. Acta 2014, 417, 79 .

${ }^{8}$ Q.-F. Sun, J. Iwasa, D. Ogawa, Y. Ishido, S. Sato, T. Ozeki, Y. Sei, K. Yamaguchi, M. Fujita, Science 2010, 328, 1144.

${ }^{9}$ C. P. Collier, E. W. Wong, M. Belohradsky, F. M. Raymo, J. F. Stoddart, P. J. Kuekes, R. S. Williams, J. R. Heath, Science 1999, 285, 391.

${ }^{10}$ H. Schmidbaur, A.Schier, Chem. Soc. Rev. 2012, 41, 370.

${ }^{11}$ J.C. Lima, L. Rodríguez, Chem. Soc. Rev., 2011, 40, 5442

12 J.C. Lima, L. Rodríguez, Inorganics 2015, 3, 1.

${ }^{13}$ A.Y.-Y. Tam, V.W.-W. Yam, Chem. Soc. Rev. 2013, 42, 1540.

${ }^{14}$ P. Casuso, A. Pérez-San Vicente, H. Iribar, A. Gutiérrez-Rivera, A. Izeta, I. Loinaz, G. Cabañero, H.-J. Grande, I. Odriozola, D. Dupin, Chem. Commun. 2014, 50, 15199.

${ }^{15}$ R. Gavara, J. Llorca, J. C. Lima, L. Rodríguez, Chem. Commun. 2013, 49, 72.

${ }^{16}$ E. Aguiló, R. Gavara, J. C. Lima, J. Llorca, L. Rodríguez, J. Mat. Chem. C 2013, 1, 5538.

17 A.J. Moro, B. Rome, E. Aguiló, J. Arcau, R. Puttreddy, K. Rissanen, J.C. Lima, L. Rodríguez, Org. Biomol. Chem. 2015, 13, 2026.

${ }^{18}$ E. Y.-H. Hong, H.-L. Wong, V. W.-W. Yam, Chem. Eur. J. 2015, 21, 5732.

${ }^{19}$ C. Po, A. Y.-Y. Tam, V.W.-W. Yam, Chem. Sci. 2014, 5, 2688.

${ }^{20}$ T. Fukino, H. Joo, Y. Hisada, M. Obana, H. Yamagishi, T. Hikina, M. Takata, N. Fujita, T. Aida, Science 2014, 344, 499.

${ }^{21}$ F. García, P. A. Korevaar, A. Verlee, E.W. Meijer, A.R.A. Palmans, L. Sánchez, Chem. Commun. 2013, 49, 8674.

${ }^{22}$ L. Rodríguez, C. Lodeiro, J.C. Lima, R. Crehuet, Inorg. Chem. 2008, 47, 4952.

${ }^{23}$ J. Buendía, L. Sánchez, Org. Lett. 2013, 15, 5746. 
${ }^{24}$ T. Rudolph, N.K. Allampally, G. Fernández, F.H. Schacher, Chem. Eur. J. 2014, 20, 13871.

${ }^{25}$ X.-S. Xiao, W. Lu, C.-M. Che, Chem. Sci. 2014, 5, 2482.

${ }^{26}$ H. Ito, T. Saito, N. Oshima, N. Kitamura, S. Ishizaka, Y. Hinatsu, M. Wakeshima, M. Kato, K. Tsuge, M. Sawamura, J. Am. Chem. Soc., 2008, 130, 10044.

${ }^{27}$ V.J. Catalano, J.M. López de Luzuriaga, M. Monge, M.E. Olmos, D. Pascual, Dalton Trans. 2014, 43, 16486.

${ }^{28}$ T. Lasanta, M.E. Olmos, A. Laguna, J.M. López de Luzuriaga, P. Naumov, J. Am. Chem. Soc. 2011, 41, 16358.

${ }^{29}$ A. Laguna, T. Lasanta, J. M. López-de-Luzuriaga, M. Monge, P. Naumov, M. E. Olmos, J. Am. Chem. Soc. 2010, 132, 456.

${ }^{30}$ D. B. Leznoff, J. Lefebvre, Gold Bull. 2005, 38, 47.

${ }^{31}$ J. Vicente, M.T. Chicote, M.D. Abrisqueta, Organometallics 1997, 16, 5628.

${ }^{32}$ E. Vergara, E. Cerrada, A. Casini, O. Zava, M. Laguna, P. J. Dyson, Organometallics 2010, 29, 2596

${ }^{33}$ R. Wanke, P. Smoleński, M.F.C. Guedes da Silva, L.M.D.R.S. Martins, A.J.L. Pombeiro, Inorg. Chem. 2008, 47, 10158.

${ }^{34}$ E. Vergara, S. Miranda, F. Mohr, E. Cerrada, E.R.T. Tiekink, P. Romero, A. Mendía, M. Laguna, Eur. J. Inorg. Chem. 2007, 2926.

35 A. Udvardy, A. Csaba Bényei, Á. Kathó, J. Organomet. Chem. 2012, 717, 116e122.

${ }^{36}$ P. Smoleński, L. Benisvy, M.F.C. Guedes da Silva, A.J.L. Pombeiro, Eur. J. Inorg. Chem. 2009, 1181.

37 L.M.D.R.S. Martins, E.C.B.A. Alegria, P. Smoleński, M.L. Kuznetsov, A.J.L. Pombeiro, Inorg. Chem. 2013, 52, 4534.

38 B. Kemper, Y.R. Hristova, S. Tacke, L. Stegemann, L.S. van Bezouwen, M.C.A. Stuart, J. Klingauf, C.A. Strassert, P. Besenius, Chem. Commun. 2015, 51, 5253.

${ }^{39}$ T.H.T. Hsu, J.J. Naidu, B.-J. Yang, M.-Y. Jang, I.J.B. Lin, Inorg. Chem. 2012, 51, 98.

${ }^{40}$ K. Holmberg, B. Jönsson, B. Kronberg, B. Lindman, Surfactants and polymers in aqueous solution, $2^{\text {nd }}$ Edition. John Wiley \& Sons, 2002.

41 D.F. Evans, H. Wennerström, The colloidal domain. Where physics, chemistry, biology and technology meet. Wiley-VCH, New York, 1994.

${ }^{42}$ L. Rodríguez, M. Ferrer, R. Crehuet, J. Anglada, J. C. Lima, Inorg. Chem. 2012, 51, 7636. 
${ }^{43}$ M. Ferrer, A. Gutiérrez, L. Rodríguez, O. Rossell, J. C. Lima, M. Font-Badía, X. Solans, Eur. J. Inorg. Chem. 2008, 18, 2899

${ }^{44}$ R. Gavara, E. Aguiló, C. Fonseca-Guerra, L. Rodríguez, J.C. Lima, Inorg. Chem. $2015, \mathbf{5 4}, 5195$.

45 A.S. Abd-El-Aziz, C.E. Carraher, P.D. Harvey, C.U. Pittman, M. Zeldin, Macromolecules Containing Metal and Metal-Like Elements, Photophysics and Photochemistry of Metal-Containing Polymer, Volume 10, John Wiley \& Sons, 2010.

${ }^{46}$ G.A. Heath, J.E. McGrady, J. Chem. Soc., Dalton Trans. 1994, 3759.

${ }^{47}$ C. Reichardt, Solvents and Solvent Effects in Organic Chemistry, Wiley-VCH, 470

Weinheim, 2003.

${ }^{48}$ S. Bagheri, H.R. Masoodi, Chem. Phys. Lett. 2015, 629, 46.

${ }^{49}$ S.K. Samanta, S. Bhattacharya, J. Mater. Chem. 2012, 22, 25277.

${ }^{50}$ C.Y.-S. Chung, V.W.-W. Yam, Chem. Eur. J. 2014, 20, 13016.

${ }^{51}$ K.M.-C. Wong, V.W.-W. Yam, Acc. Chem. Res. 2011, 44, 424.

${ }^{52}$ M. J. Kamlet, R. W. Taft, J. Am. Chem. Soc. 1976, 98, 377.

${ }^{53}$ P. W. Carr, J. Chromatogr. 1980, 194, 105.

${ }^{54}$ Y. Zhong, Z. Jiao, Y. Yu, Biomed. Chromatogr. 2006, 20, 319.

${ }^{55}$ M. J. Kamlet, R. M. Doherty, R. W. Taft, M. H. Abraham, W. J. Koros, J. Am. Chem. Soc. 1984, 106, 1205.

${ }^{56}$ L. Rodríguez, M. Ferrer, O. Rossell, F. J.S. Duarte, A. G. Santos, J. C. Lima, J. Photochem. Photobiol. A: Chemistry 2009, 204, 174.

${ }^{57}$ N. Aliaga-Alcalde, L. Rodríguez, Inorg. Chim. Acta 2012, 380, 187.

${ }^{58}$ A. L. Balch, Gold Bull. 2004, 37, 45.

${ }^{59}$ M.A. Malwitz, S.H. Lim, R.L. White-Morris, D.M. Pham, M.M. Olmstead, A.L. Balch, J. Am. Chem. Soc. 2012, 134, 10885.

${ }^{60}$ S. Kalgutkar, N. Castagnoli, J. Med. Chem. 1992, 35, 4165.

${ }^{61}$ Z. Assefa, B.G. McBurnett, R.J. Staples, J.P. Fackler, B. Assmann, K. Angermaier, H. Schmidbaur, Inorg. Chem. 1995, 34, 75.

${ }^{62}$ J. Vicente, M. Chicote, Inorg. Synth. 1998, 32, 172.

${ }^{63}$ S. Rubinsztajn, W.K. Fife, M. Zeldin, Tetrahedron Lett. 1992, 33, 1821. 


\section{TOC synopsis}

The synthesis of different cationic gold(I) complexes gave rise to the formation of unexpected supramolecular assemblies in water going from rod-like structures to vesicles and square-like structures. The aggregation process has been observed to be dependent on the counterion, the position of the positive charge and the solvent. 


\section{Graphical Abstract}

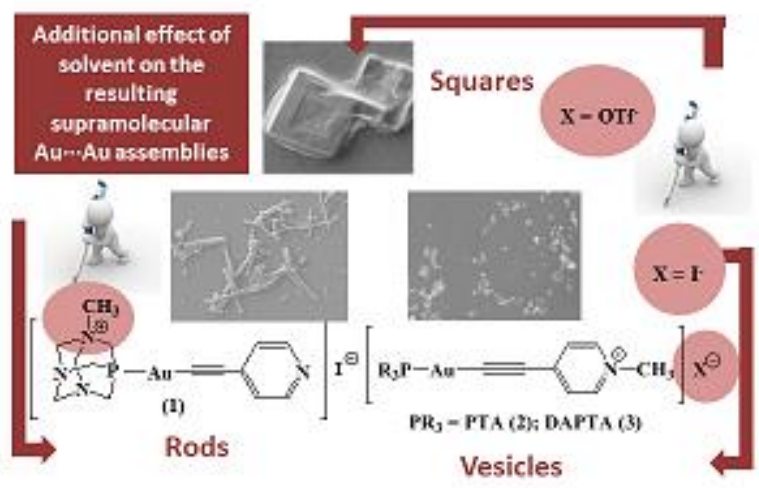

